\title{
Evidence for large Holocene earthquakes along the Denali fault in southwest Yukon, Canada
}

Authors: A. Blais-Stevens, J.J. Clague, J. Brahney, P. Lipovsky, P. Haeussler, B. Menounos

\begin{abstract}
The Yukon-Alaska Highway corridor in southern Yukon is subject to geohazards ranging from landslides, to floods, and earthquakes on faults in the St. Elias Mountains and Shakwak Valley. Here we discuss the late Holocene seismic history of the Denali fault, located at the eastern front of the St. Elias Mountains and one of only a few known seismically active terrestrial faults in Canada. Holocene faulting is indicated by scarps and mounds on late Pleistocene drift and by tectonically deformed Pleistocene and Holocene sediments. Previous work on trenches excavated against the fault scarp near Duke River reveals paleoseismic sediment disturbance dated to $c a$. 300-1200, 1200-1900, and 3000 years ago. Re-excavation of the trenches indicate a fourth event dated to 6000 years ago. The trenches are interpreted as a negative flower structure produced by extension of sediments by dextral strike-slip fault movement. Nearby Crescent Lake is ponded against the fault scarp. Sediment cores reveal four abrupt sediment and diatom changes reflecting seismic shaking at $c a$. 1200-1900, 1900-5900, 5900-6200, and 6500-6800 years ago. At Duke River, the fault offsets sediments, including two White River tephra layers ( $c a .1900$ and 1200 years old). Late Pleistocene outwash gravel and overlying Holocene aeolian sediments show in cross-section a positive flower structure indicative of postglacial contraction of the sediments by dextral strike-slip movement. Based on the number of events reflecting $\sim$ M6, we estimate the average recurrence of large earthquakes on the Yukon part of the Denali fault to be about 1300 years in the last $6500-6800$ years.
\end{abstract}

\section{Introduction}

Natural Resources Canada through its Public Safety Geoscience program carries out geologic research to identify natural hazards in Canada. A component of this program is the study of faults on the Canadian landmass that might be seismically active and thus pose a potential hazard to life and the built environment. To date, few faults, aside from those offshore of the coast of British Columbia near active plate boundaries, have been shown to be active and thus 
capable of producing damaging earthquakes. Recently, the Leech River fault, located in southern Vancouver Island, southwestern British Columbia, has been documented as a seismically active fault (Morell et al., 2018). Another seismically active fault is the Denali, a major intracontinental dextral strike-slip fault that has been active since the Early Cretaceous. It is more than $2000 \mathrm{~km}$ long, extending from northwest British Columbia to southwest Alaska (Figure 1; Grantz, 1966; Eisbacher, 1976; Lanphere, 1978; Dodds, 1995; Lowey, 1998). The Alaska section of this fault generated a $\mathrm{M}_{\mathrm{w}} 7.9$ earthquake in November 2002 and subsequently was well studied (Eberhart-Phillips et al., 2003; Haeussler et al., 2004, 2017; Matmon et al., 2006; Haeussler, 2008, 2009). The Yukon section of the fault, in contrast, is less well studied (Clague, 1979; Haeussler et al., 2017) and historically has produced only a few small earthquakes. Bender and Haeussler (2017), however, have recently published a map showing the surface trace of the eastern Denali fault in Alaska and Yukon.

The 2002 earthquake ruptured the central section of the Denali fault, which has the highest late Quaternary average slip rate $(\sim 13 \mathrm{~mm} / \mathrm{yr})$ west of its intersection with the Totschunda fault (Figure 1, red arrow and thick red line; Matmon et al., 2006; Hauessler et al., 2017). To the west of the 2002 epicenter, over a distance of $575 \mathrm{~km}$, the average slip rate has been estimated at $\sim 5 \mathrm{~mm} / \mathrm{year}$ and to the east, i.e., roughly $280 \mathrm{~km}$ southeast of the TochungaDenali intersection (Figure 1), 2 mm per year (Haeussler et al., 2017). Marechal et al. (2018) estimated dextral strike-slip motion reducing to less than $1 \mathrm{~mm} / \mathrm{yr}$ along the eastern Denali fault, approximately $80 \mathrm{~km}$ south of the Denali-Totschunda junction.

In this paper, we report evidence for Holocene seismic activity and displacements on the eastern portion of the Denali fault, i.e., the Shakwak segment, in the vicinity of Kluane Lake, 
Yukon (Figure 2). We document geomorphic evidence of these displacements; describe and reinterpret paleoseismic trenches excavated by scientists from the U.S. Geological Survey, Yukon Geological Survey, and Simon Fraser University (Seitz et al., 2008; Lipovsky et al., 2009); describe and interpret sediment cores collected from a small lake impounded by the fault scarp; and finally describe deformation of sediments intersected by a strand of the fault in a bluff along the Duke River. We attempt to correlate inferred paleoseismic events in three different, but spatially close settings, subject to the limits of radiocarbon dating (sites D, E, and F, Figure 2c).

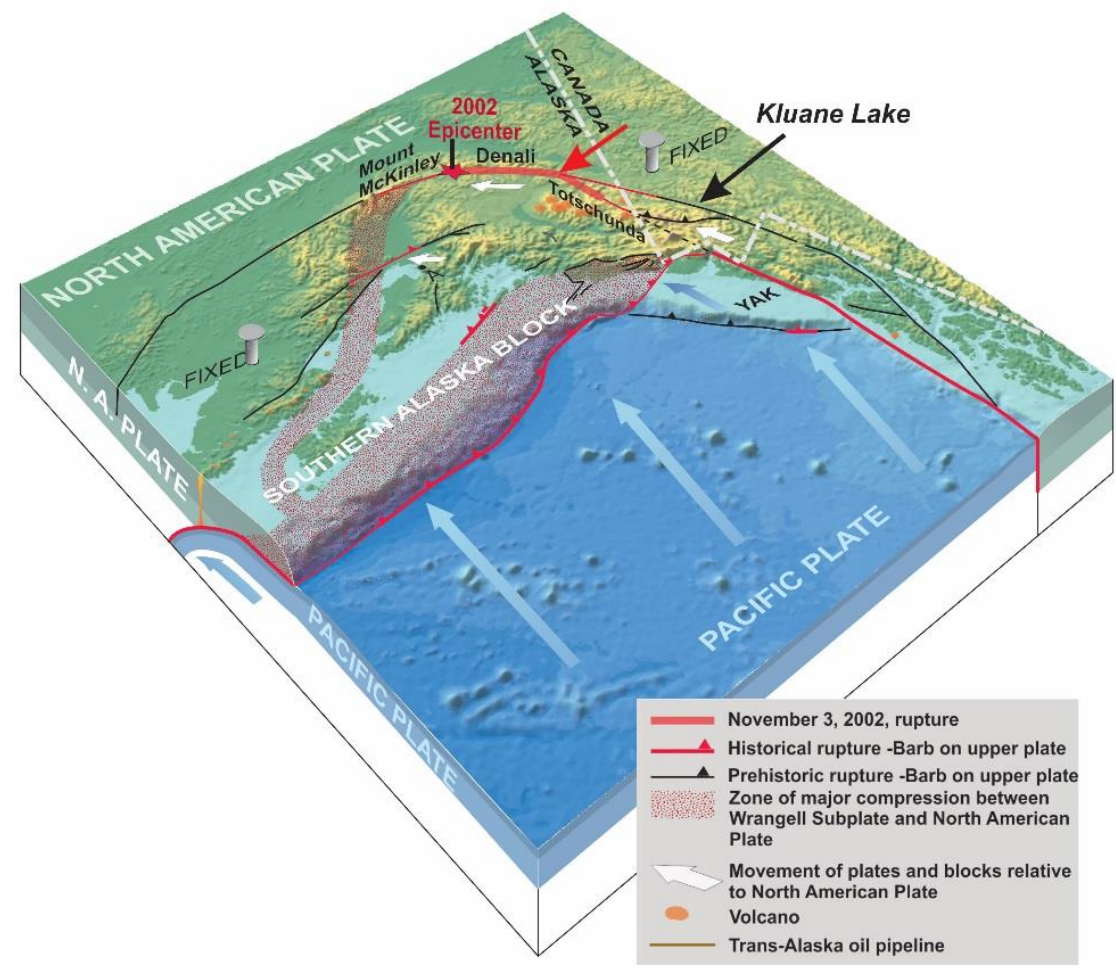

Figure 1. Denali fault system, the tectonic plates that control it, and the study area near Kluane Lake. The Pacific Plate is subducting beneath the North America Plate at a rate of $\sim 50 \mathrm{~mm} / \mathrm{yr}$. The Denali and Totschunda faults are located at the northeastern edge of the Wrangell subplate. The red arrow marks the intersection of the Denali and Totschunda faults and the division between the western and eastern segments of the Denali fault. The average slip rate on the Denali fault east of this intersection is less than half that to the west (Haeussler et al., 2017). Diagram modified from Fuis and Wald (2003) and Elliott et al. (2010). 

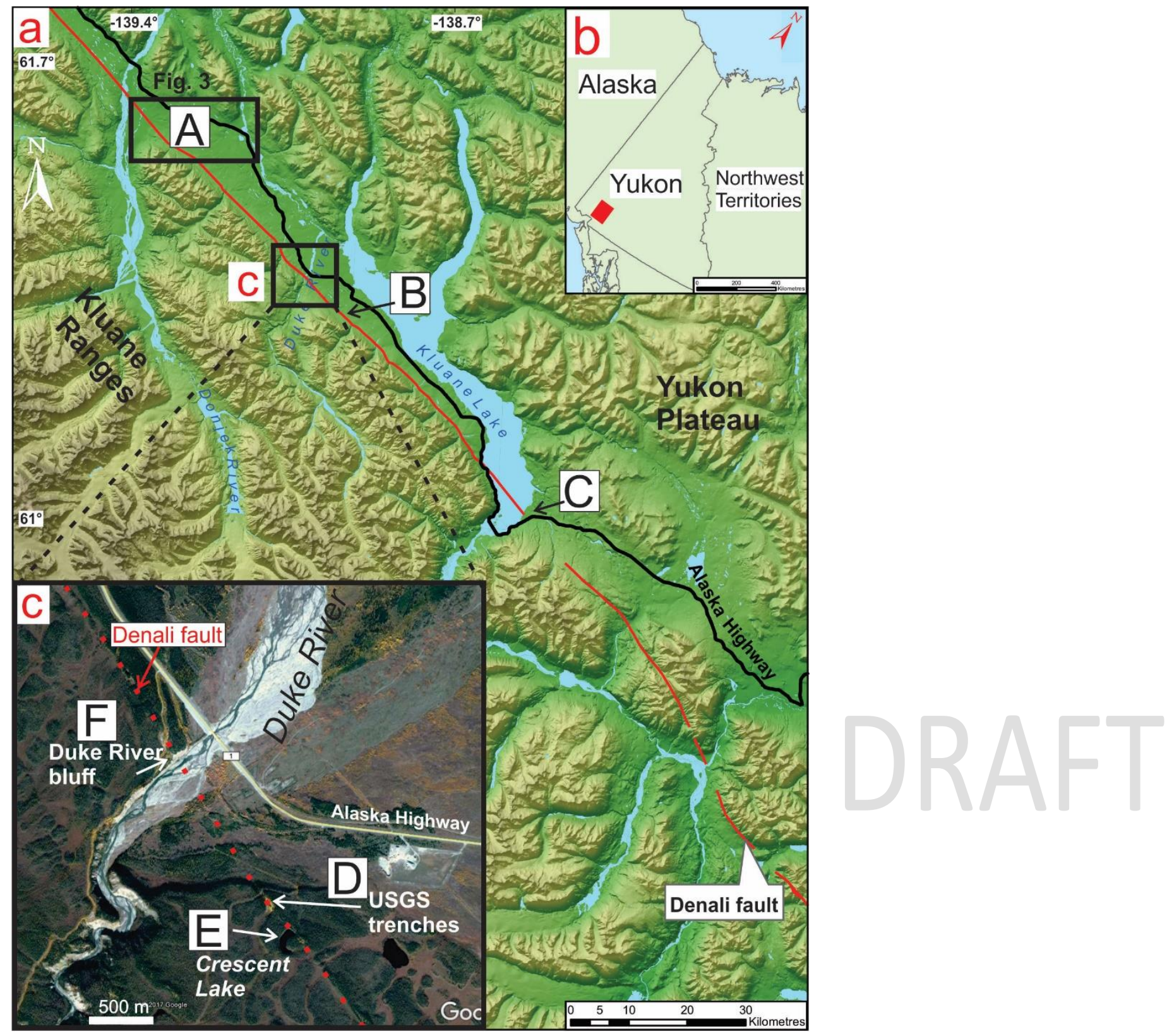

Figure 2. a) Study sites A, B, and C (black letters). The red line is the approximate trace of the Denali fault. b) Location of study area (red rectangle) in Yukon. c) Locations of sites D, E, and F (black letters) near Duke River (Google Earth image).

\section{Setting}

The Denali fault separates the Kluane Ranges, located within the St. Elias Mountains, from the 
Ruby Range in the Yukon Plateau (Figure 2; Mathews, 1986; Huscroft et al., 2004). Bedrock comprises volcanic, volcaniclastic, and sedimentary rocks ranging in age from Permian to Jurassic (Dodds and Campbell, 1992).

Permafrost in the area is sporadic and discontinuous, with less than $10 \%$ ground ice to depths of 10-20 m below the ground surface (Heginbottom and Radburn, 1992; Heginbottom, 1995). At the three sites that we studied (D, E, and F, Figure 2c), no obvious permafrost features were observed at the surface or during trenching and coring.

The study area is characterized by a subarctic continental climate with long cold winters and short warm summers. The climate has is semiarid, with an average of $340 \mathrm{~mm}$ of precipitation per year. The average monthly temperatures in January are $-22^{\circ} \mathrm{C}$ and in July, $13^{\circ} \mathrm{C}$ (Huscroft et al., 2004; Northern Climate ExChange, 2013).

The area has undergone several Quaternary glaciations, the last of which was the McConnell Glaciation ( 22-12.5 ka), during which glaciers filled the Shakwak Trench and flowed towards the northwest (Figure 3; Rampton, 1981; Duk-Rodkin 1999; Huscroft et al., 2004).

Two explosive volcanic eruptions occurred 1900 and 1200 years ago from a source near Mt. Bona and Mt. Churchill in the St. Elias Mountains in eastern Alaska (McGimsey et al., 1990; Clague et al., 1995; Lerbekmo, 2008). The older eruption left a thin tephra layer that extends to the north along the Yukon-Alaska boundary, whereas the younger eruption produced a larger tephra layer that covers southern Yukon and areas to the east and south (McGimsey et al., 1990; Lerbekmo, 2008). Together, the two White River tephras are found over an area of about $340,000 \mathrm{~km}^{2}$ and have a volume of $25-30 \mathrm{~km}^{3}$. Where the two lobes overlap, the tephra 
layers are commonly separated by a thin layer of organic sediment or loess. Typically, the older tephra is finer and thinner than the younger one (McGimsey et al., 1990; Lerbekmo, 2008).

\section{Methods}

We used aerial photographs, Google Earth satellite imagery, and lidar images to document surface displacements along the Denali fault (sites A, B, and C; Figures 2a and c). Seitz et al. (2008) excavated three trenches perpendicular to the fault (site D, Figure 2c).

We revisited and deepened U.S. Geological Survey trenches T2 and T3 in 2011 and 2013. Trench 1(T1) was not re-excavated due to a high water table. Trench $\mathrm{T} 3$ was the largest and deepest of the three and is the focus of this study. It measured up to $7 \mathrm{~m}$ long and $2 \mathrm{~m}$ deep. Age control is provided by 1) the two late Holocene White River tephra layers; 2) non-faulted 300 year-old shorelines of Kluane Lake (Clague et al., 2006; Brahney et al., 2010) crossed by the Denali fault; and 3) AMS radiocarbon ages on plant remains in the trench sediments, in Crescent Lake cores, and the Duke River bluff. The two samples at Duke River were collected as follows: one just below the younger tephra and the other, just above the older tephra. Elevations of the Duke River samples (Table 1) appear inverted, but this is due to the irregular surface at the top of the bluff.

We affixed strings on the vertical faces of the hand-excavated trench walls to establish a grid $\left(0.5 \mathrm{~m}^{2}\right)$ to facilitate mapping of sediments and structures. We photographed the trench walls and created a georeferenced orthophoto of the wall that we used for mapping. Two samples of wood and charcoal from trench T3 were radiocarbon-dated to supplement the radiocarbon ages reported by Seitz et al. (2008).

We collected four $7.5 \mathrm{~cm}$-diameter sediment cores from Crescent Lake (site E, Figure 
2c), a shallow pond 200 m southeast of the trenches (site D). Crescent Lake has an area of about 1.7 ha and a maximum depth of about $4 \mathrm{~m}$. We made two attempts to core the lake. A single short $(73 \mathrm{~cm})$ percussion core (labeled core 2) was collected from the center of the lake in the summer of 2008. An additional three vibracores up to $106 \mathrm{~cm}$ in length were collected from the frozen surface of the lake in March 2010 along a transect perpendicular to the fault scarp (labeled cores 1, 3, and 4).

A fibrous rooty peat that prevented core penetration in 2008 also stopped the vibracorer in 2010. We transported all cores to the University of Northern British Columbia in Prince George, British Columbia, where they were split, photographed, and logged. Radiocarbon ages on eight samples of subfossil plant remains from the cores were determined at the University of California Irvine Keck Carbon Cycle AMS Laboratory.

We analyzed two of the four Crescent Lake cores (nos. 2 and 4) for diatom concentrations and species composition. Prior to the preparation of each slide, $5 \mathrm{mg}$ of dry sediment were digested in $20 \%$ hydrogen peroxide solution and placed in a water bath for 2 days. The digested sediment was rinsed with de-ionized water and left to settle for at least 24 hours before being aspirated and further rinsed (Battarbee et al., 2001). Diatom slides were mounted in Battarbee trays to allow for counts of microfossils per gram of sediment. Diatom species were identified from taxonomic literature (Patrick and Reimer, 1966, 1975; Krammer and Lange-Bertalot, 1985, 1986, 1988, 1991, 2000; Kelly et al., 2005) and internet resources (Spaulding et al., 2010). Diatoms were identified and counted using an Olympus® BX51 Photomicroscope with DIC optics.

We described and photographed deformed Late Pleistocene and Holocene sediments in a 
bluff on the north side of Duke River, just upstream of the Alaska Highway (site F, Figure 2c).

\section{Results and Discussion}

\subsection{Geomorphic expression of the fault}

Clague $(1979,1982)$ identified a nearly continuous Holocene offset along the Denali fault from near the Alaska-Yukon boundary to the southern end of Kluane Lake (Figure 2a). The fault displaces drumlins and flutings produced by northwest-flowing glacier ice during the McConnell Glaciation (Marine Isotope Stage 2; Rampton, 1979, 1981; Klassen, 1987; DukRodkin, 1999; site A, Figure 2a; and Figure 3). The fault trace is locally marked by elongate mounds that were interpreted by Seitz et al. (2008) and Hauessler et al. (2017) to be tectonic push-ups formed by shortening between en échelon left-stepping fault strands (Figure 4). Here, we interpret the mounds as positive flower structures and the depressions as negative flower structures that formed, respectively, at sites of local compression and extension between en échelon fault strands during strike-slip movement (Harding, 1985; Woodcock and Fischer, 1986; see section 4.2). We identified and measured 538 mounds over a distance of about $110 \mathrm{~km}$ along the length of the fault in Yukon. The mounds average $90 \mathrm{~m}$ in length, $60 \mathrm{~m}$ in width, and are up to $10 \mathrm{~m}$ in height; the average spacing between mounds is about $125 \mathrm{~m}$.

Very few fault mounds show measurable lateral displacement. However, at site B, Figure 2a, mounds are offset by 20-30 m (Figure 4; Seitz et al., 2008; Haeussler et al., 2017). Examination of aerial photographs (1980s National Air Photo Library) and Google Earth imagery (DigitalGlobe 2016) shows that the mounds and depressions lie within a fault zone, the strands of which penetrate both bedrock and overlying Late Pleistocene and Holocene sediments. 
Fault displacement is also visible on a lidar hill shade image of the floodplain of Duke River just southwest of the Alaska Highway (Figure 5a). There it extends across a low terrace less than $1 \mathrm{~m}$ above the active braidplain of the river, a surface that is likely less than 1000 years old (Clague et al., 2006). Marechal et al. (2018) documented a line of fault mounds crossing the floodplain of Koidern Creek, $70 \mathrm{~km}$ northwest of Duke River. The southernmost

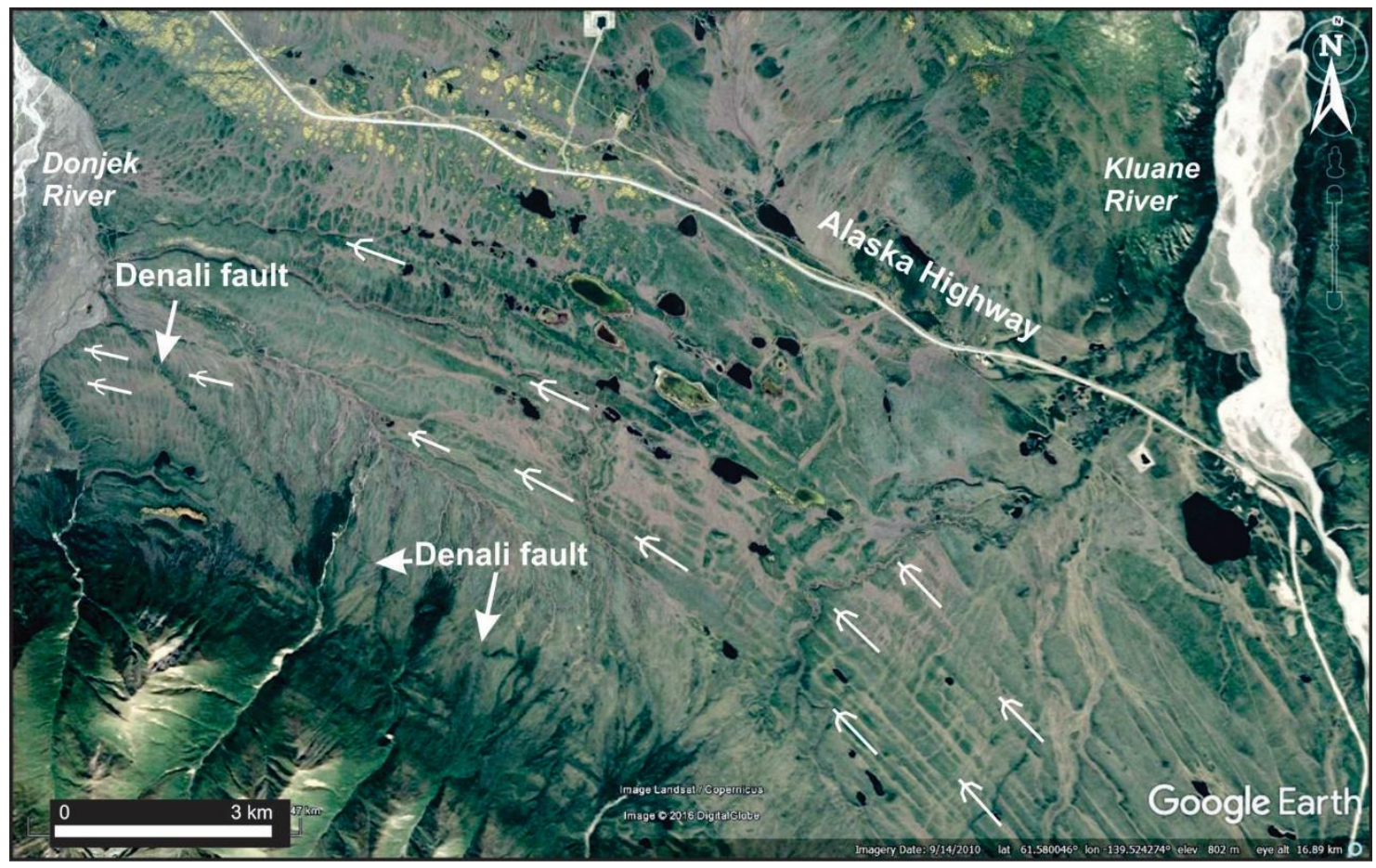

Figure 3. Trace of the Denali fault mounds in the vicinity of site A. The fault cuts late Pleistocene glacier flutings oriented towards the northwest (white curved arrows). 


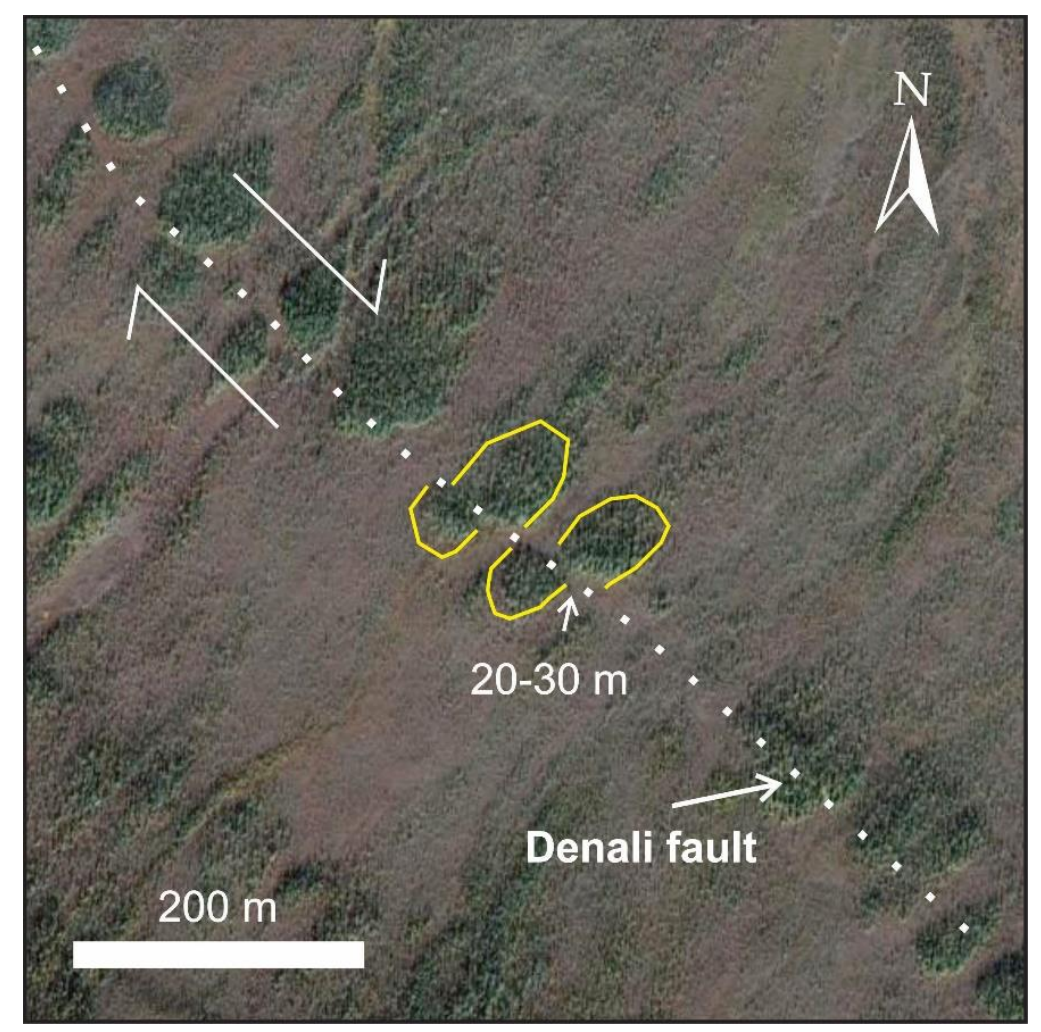

Figure 4. Google Earth image showing inferred offsets of mounds along the Denali fault at site B. Seitz et al. (2008) documented offsets at this site, and Haeussler et al. (2017) estimated the total displacements to be $20-30 \mathrm{~m}$.

morphological expression of the Denali fault in our study area is a series of mounds truncating the surface of a postglacial alluvial fan south of Kluane Lake (site C in Figure 2a; Figure 6).

All fault displacements east of the Alaska-Yukon border postdate terminal Pleistocene deglaciation of the Kluane Lake area, which has been dated at about 12,500 years ago (Rampton, 1981). This date and offsets of mounds yield an average horizontal slip-rate over the Holocene of $2 \mathrm{~mm} / \mathrm{yr}$. Haeussler et al. (2017) provided a range of 1.5-2.3 mm/yr for the Yukon segment of the Denali fault, but noted that the average slip rate for the Holocene is probably closer to the upper end of this range because the mounds may have started to form well after deglaciation. Our findings support these previously reported slip rate estimates. 


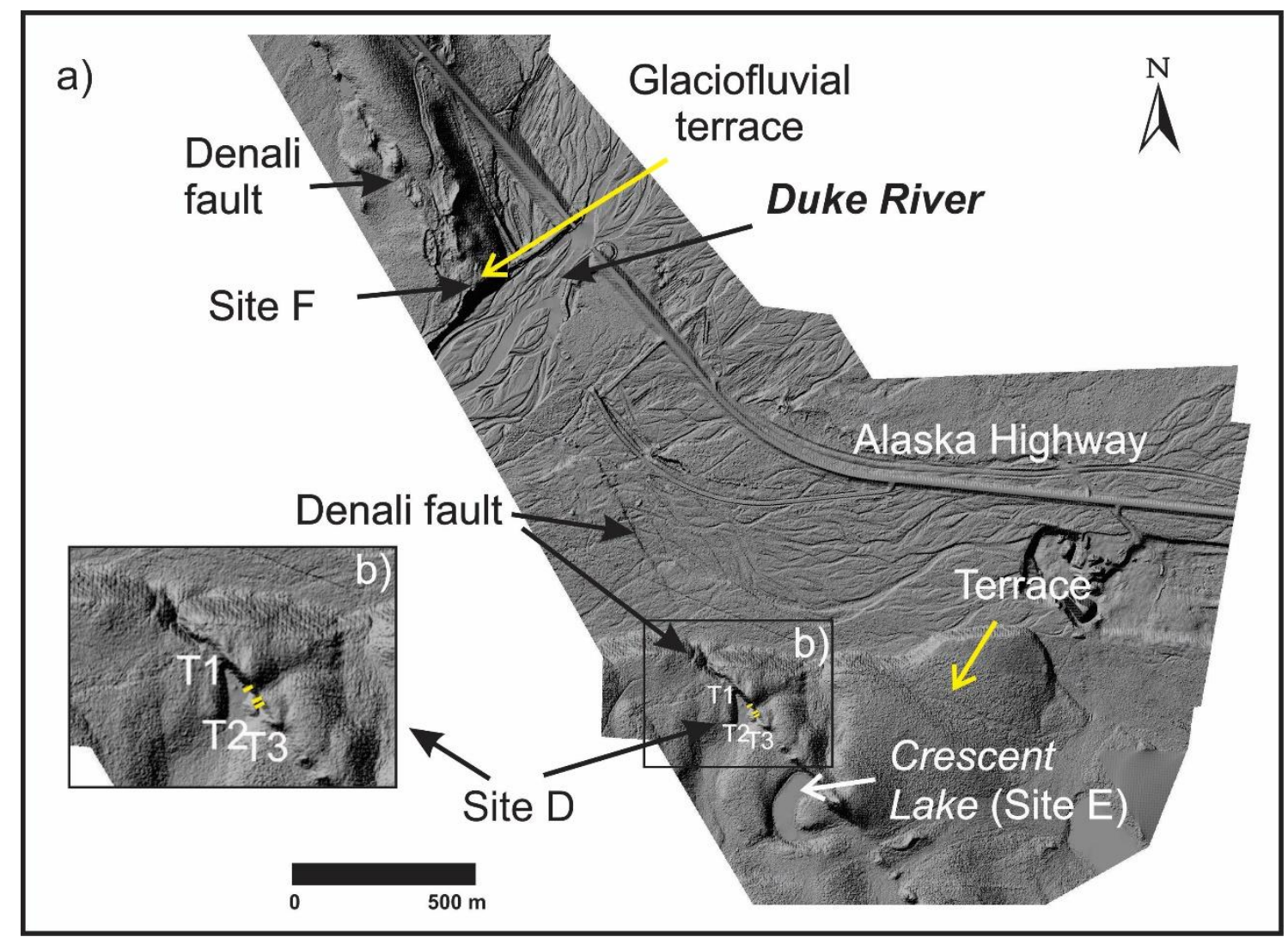

Figure 5. a) Lidar image of a fault-offset fluvial terrace at Duke River just upstream of the Alaska Highway. Also shown are the locations of sites D, E, and F (see also Figure 2c for locations). b) Close-up of lidar image showing the locations of the three trenches. Source: Yukon Geological Survey.

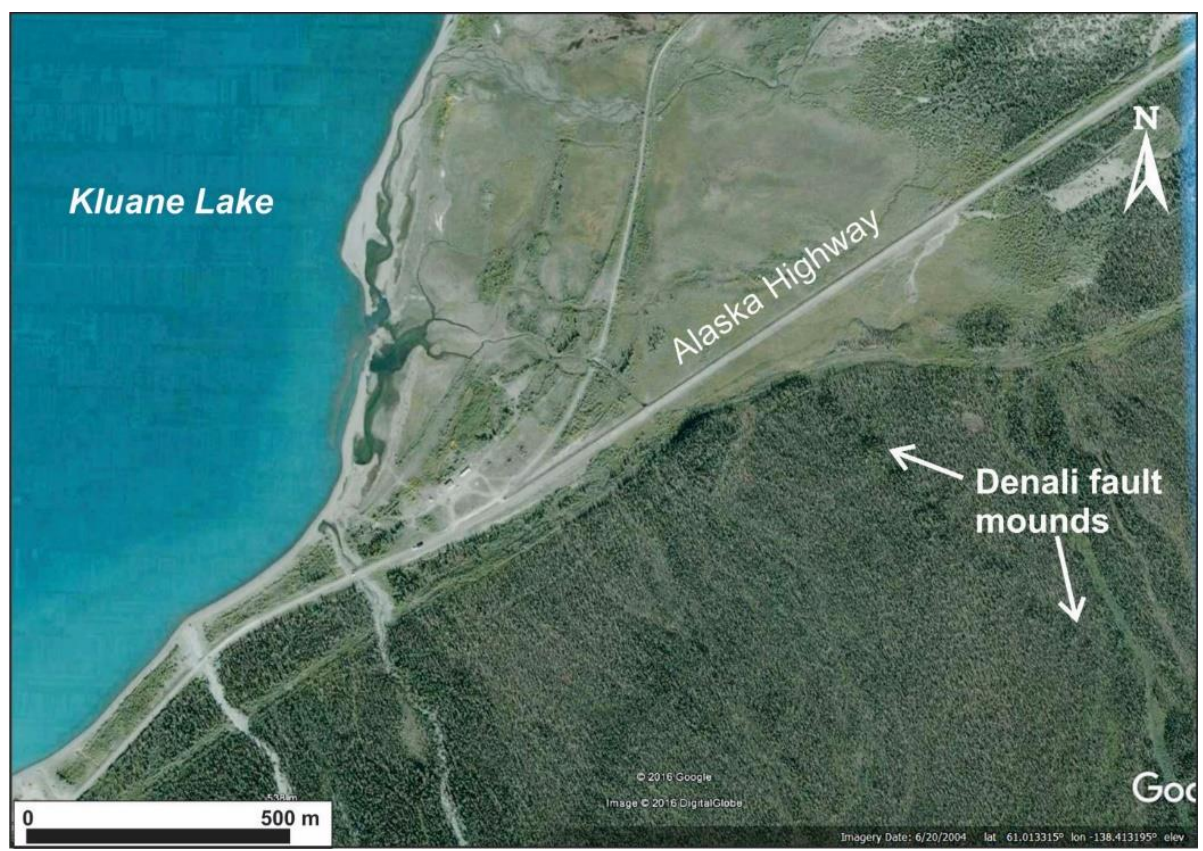


Figure 6. Fault mounds on a postglacial alluvial fan just south of Kluane Lake (site C, Figure 2a). This site is the southernmost geomorphological expression of the fault.

\subsection{Palesoseismic evidence in trenches}

Two of the three trenches (T2 and T3) at site D (Figures 2c, 5a and b, 7a and b) record three large earthquakes in the past 3000 years (Seitz et al., 2008). To recapitulate, T2 and T3 show evidence of coseismic deformation, including faulted and folded strata forming the fill within the depression adjacent to the fault scarp (see Appendix 1). The evidence includes the two deformed White River tephra layers, fissure fills, upward truncations on inferred faults, stratigraphic mismatches, and colluvial wedges that likely formed soon after three large earthquakes (Figures 7a and b). The green and blue lines are discontinuous and faulted horizons and the red lines are faults and/or fissures (Figure 7a). The orange line in Figure 7a was labeled free face (i.e., slope profile) or fault (Figure 7a). In Figure 7b, it is interpreted as a fault. We recognized a fourth potential seismic event in faulted sediments exposed when we deepened trench T3 (event 4, black fault line in Figure 7b; Table 1). A fourth event was also documented in T2 (Seitz et al., 2008). Further details on all the paleoseismic features in the trenches are provided by Seitz et al. (2008) and included Appendix 1.

The older White River tephra is present as small scattered and stretched blebs, which we interpret to record coseismic sediment deformation. The younger White River tephra layer is thickest in the center of the trench and is discontinuous and has a bleb-like structure adjacent to the scarp. It is offset by a fault strand in trench T2 (Seitz et al., 2008; Appendix 1). We interpret the sediments within the trenches to show extensional deformation in a negative flower structure 
produced by dextral strike-slip movement (red dashed lines in Figure 7b; Figure 7c).

Although we do not know how much slip happened during each earthquake, the fact that the fault ruptured the surface suggests that the events were large, in range of magnitude 6-7 or larger (Eberhart-Phillips et al., 2003; Haeussler et al., 2004; Matmon et al., 2006). The relatively small number of events in the past several thousand years, however, is consistent with the regional tectonic model that hypothesizes much lower slip rates on the Yukon segment of the Denali fault than on the Alaska segment (Matmon et al., 2006; Haeussler et al., 2017).

The most recent rupture occurred after deposition of the 1200 year-old White River tephra, but prior to the formation of the raised Kluane Lake shorelines less than 300 years ago (Clague et al., 2006). Based on the radiocarbon ages from the trenches, Seitz et al. (2008) assigned ages of 300-1200 (event 1), ca. 2200 (event 2), and 3000 (event 3) cal yr BP to earthquakes. A fourth inferred earthquake, mentioned above, is assigned an age of ca. 5900$6200 \mathrm{cal}$ yr BP. Uncertainties are inherent in dating paleoseismic events owing to potential errors in calibrated radiocarbon ages and to the stratigraphic relationship of dated sediments to earthquake events. Moreover, deformation is likely driven, not only by fault slip at depth, but also by gravitational movements from the fault scarp in an extensional setting, i.e., a negative flower structure (Figure 7c; Woodcock and Fisher, 1986).

\subsection{Paleoseismic evidence from Crescent Lake cores}

Basal sediments in three of the four Crescent Lake sediment cores consist of dark brown, woody, fibrous peat (Figures $8 \mathrm{a}$ and b; Table 1). In two of the cores (1 and 4), this peat is abruptly overlain by a terrigenous silt unit (blue unit in Figure 8a), which is in turn overlain by an organic-rich silt (olive grey). Gyttja (beige unit in Figure 8a) is the dominant sediment in 


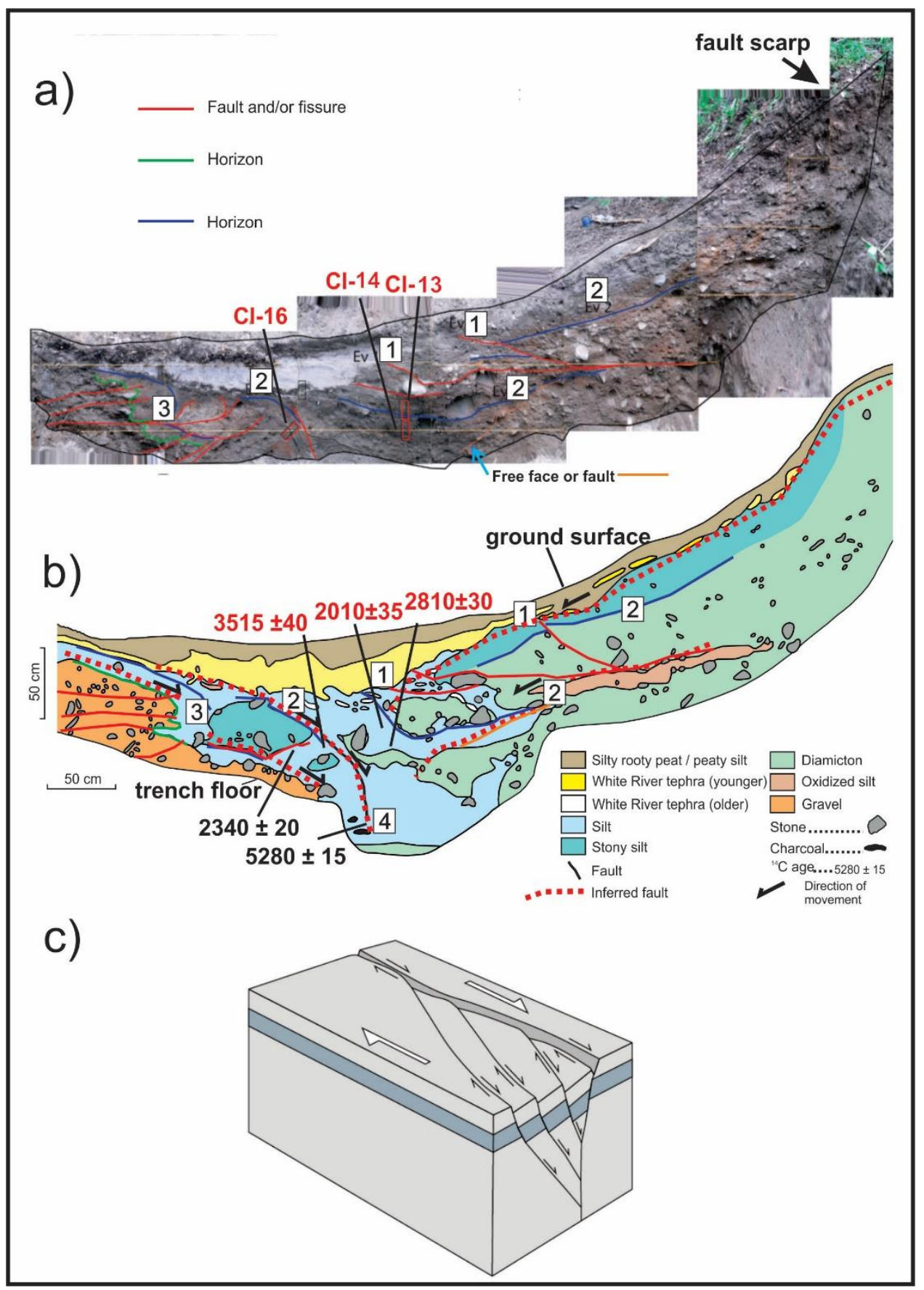

Figure 7. Stratigraphy of trench T3 (Figure 2c, site D). a). Photomosaic of the trench from Seitz et al. (2008), view to the north. Seismic events (Ev) 1, 2, and 3 (ca. 0.3-1.2, 2.2, and $3.0 \mathrm{ka}$ ) are labeled; Cl-13, Cl-14, and Cl-16 (in red) are ${ }^{14} \mathrm{C}$ ages reported by Seitz et al. (2008) (Table 1). b) Interpreted stratigraphy of the same trench showing a fourth seismic event and the full set of radiocarbon ages. The older White River tephra (1.9 ka) is shown as small scattered white blebs in the center of the trench and the younger tephra $(1.2 \mathrm{ka})$ is colored bright yellow. c) The trench face is interpreted as a negative flower structure with red dashed lines indicating inferred faults and arrows showing a downward direction of movement. 
Table 1. Radiocarbon ages.

\begin{tabular}{|c|c|c|c|c|c|}
\hline \multicolumn{3}{|c|}{ Ages from USGS trench 3 (Seitz et al., 2008) } & & & \\
\hline Sample \# & Radiocarbon age & $\begin{array}{c}\text { Calibrated age range yrs } \\
(\text { (BP)* }\end{array}$ & $\begin{array}{c}\text { Trench depth } \\
\text { (m) }\end{array}$ & \multicolumn{2}{|c|}{ Dated material } \\
\hline CL-13 & $2010 \pm 35$ & $1880-2054$ & 0.25 & \multicolumn{2}{|c|}{ plant fibers/peat } \\
\hline CL-14 & $2810 \pm 30$ & 2844-2999 & 0.4 & \multicolumn{2}{|c|}{ plant fibers/peat } \\
\hline CL-16 & $3515 \pm 40$ & $3650-3895$ & 0.5 & \multicolumn{2}{|c|}{ plant fibers/peat } \\
\hline \multicolumn{6}{|c|}{ Ages from revisited USGS trench \#3 } \\
\hline UCIAMS 134801 & $3240 \pm 20$ & $3556-3495$ & 1 & wood & \\
\hline UCIAMS 134803 & $5280 \pm 15$ & $5960-6178$ & 1.5 & charcoal & \\
\hline \multicolumn{6}{|c|}{ Ages from Crescent Lake sediment cores } \\
\hline Sample \# & Radiocarbon age & $\begin{array}{c}\text { Calibrated age range yr } \\
\text { (BP)* }\end{array}$ & $\begin{array}{l}\text { Core depth } \\
\text { (cm) }\end{array}$ & \multicolumn{2}{|c|}{ Dated material } \\
\hline UCIAMS 83763 & $5210 \pm 150$ & $5660-6290$ & Core 1,76 & plant fibers & \\
\hline UCIAMS 83764 & $5820 \pm 170$ & $6290-7150$ & Core 1,80 & plant fibers & \\
\hline UCIAMS 83765 & $5880 \pm 30$ & $6640-6780$ & Core $1,82.5$ & plant fibers & \\
\hline UCIAMS 83766 & $5795 \pm 25$ & $6500-6660$ & Core 1,85 & plant fibers & \\
\hline UCIAMS 79274 & $2040 \pm 15$ & $1940-2050$ & Core 2,48 & plant fibers & \\
\hline UCIAMS 109492 & $430 \pm 20$ & $471-520$ & Core 4,43 & plant fibers & \\
\hline UCIAMS 109493 & $1840 \pm 15$ & $1722-1821$ & Core 4,54 & plant fibers & \\
\hline UCIAMS 109494 & $3735 \pm 40$ & $3975-4233$ & Core 4,98 & plant fibers & \\
\hline Ages from Duke & River bluff & & $\begin{array}{c}\text { Depth from } \\
\text { surface }(\mathbf{m})\end{array}$ & & \\
\hline UCIAMS 134799 & $1460 \pm 15$ & $1310-1380$ & 0.6 & wood & \\
\hline UCIAMS 134800 & $1805 \pm 15$ & $1700-1800$ & 0.3 & wood & \\
\hline
\end{tabular}

*Calibrated age ranges $(2 \sigma)$ were calculated using OxCal v. 4.3.2 (Bronk Ramsey, 2017) and the IntCal13 atmospheric curve (Reimer et al., 2013).

Crescent Lake. It overlies the clastic organic-rich silt layer near the base of the cores. Subtle differences in lithology are indicated by color differences and by the amount of clay, silt, and sand in the gyttja. The two White River tephra layers are present in three of the four cores; only the younger tephra was found in core 4 (Figure 8a).

Diatom data allowed us to refine stratigraphic correlations between cores 2 and 4 (colorcoded dots in Figure 8). They also revealed that the upper and lower radiocarbon ages in core 4 are too young, likely due to sediment mixing, possibly by bioturbation (Figure 8a; Table 1; 
Appendix 2, Supplementary Figure 1). Dominant diatom species at the base of the two cores (core 2: $69 \mathrm{~cm}$; core 4: 90-96 cm) are pioneering benthic species (Pseudostaurosira brevistriata, Staurosirella pinnata, and Staurosira construens), which commonly constitute the bulk of initial diatom communities in early Holocene subarctic sediments (Appendix 2, Supplementary Figures 2 and 3; Lotter et al., 2010). This assemblage is followed by a sudden rise in planktonic species that require deeper waters to achieve active lake mixing (Aulacoseirs spp.). The transition from species characteristic of wetlands (peat) to planktonic species is consistent with sudden deepening of a wetland into a lake (organic-rich silt). We attribute the deepening to the formation of a sag pond due to subsidence along a fault scarp during an earthquake (McCalpin et al., 2009). We ruled out climatic or hydrologic factors as potential causes of sudden deepening of the wetland because there is no evidence of surface flow into the lake or thermokarst subsidence at this site. The age of this event (6500-6800 cal yr BP) was estimated from the radiocarbon ages of samples collected from the top of the peat and from the overlying silt layer in core 1 (Figure $8 \mathrm{a}$, Table 1).

Marked increases in diatom flux, albeit with decreases in species richness, characterize several levels in the gyttja above the basal sediments in core $4(88,55$, and $41 \mathrm{~cm}$; Appendix 2; Supplementary Figure 3). These intervals likely represent intermittent disturbances of the lake system, perhaps accompanied by a sudden increase in nutrients or a shift in benthic habitat affecting diatom production; we infer that they are responses to seismic shaking and movements on the nearby fault. As we have argued for the older subsidence event, it is unlikely climatic and hydrologic factors are responsible for these disturbances due to the cold dry climate and the absence of streams flowing into the lake. We infer that the silt layer at $88 \mathrm{~cm}$ in core 4 correlates with the silt layer in core $1(5900-6200 \mathrm{cal} \mathrm{yr} \mathrm{BP})$ and the clay layer in core 2 . The silt layer at 
$55 \mathrm{~cm}$ in core 4 is not easily correlated with silt layers in the other cores due to uncertainties in its age.

The silt layer between the two White River tephras in cores 1, 2, and 3 and below the youngest tephra in core 4 has an age range of 1900 to 1200 years ago. Diatoms are rare in this layer in cores 2 and 4, indicating rapid sedimentation of terrigenous rather than organic material. The only diatom species that is present (Eunotia panda), albeit in low numbers, is characteristic of shallow water or bog habitats (Veselá, 2015), indicating that it was likely transported to the lake floor. Nitzschia amphibia, a benthic species that is sensitive to turbidity and is otherwise common in cores 2 and 4, is absent in the silty layers sampled, whereas other pioneering benthic species increase in abundance in these layers (Appendix 2; Supplementary Figure 2). We infer that this silt layer is the result of seismic shaking. It may correlate with event 2 (ca. $2200 \mathrm{cal} \mathrm{yr}$ BP) of Seitz et al. (2008); if so, event 2 is younger than 2200 cal yr BP.

Core 4 is closest to the fault scarp and thus most likely to record influxes of sediment from the scarp (e.g., sandy layers colored orange in Figures 8a and b). These coarse layers could also have formed during earthquakes by the partitioning and redeposition of the clastic component of gyttja within the lake, as documented in Lake Témiscaming (northern Québec) following a magnitude 6.3 earthquake in 1935 (Doig, 1991). 


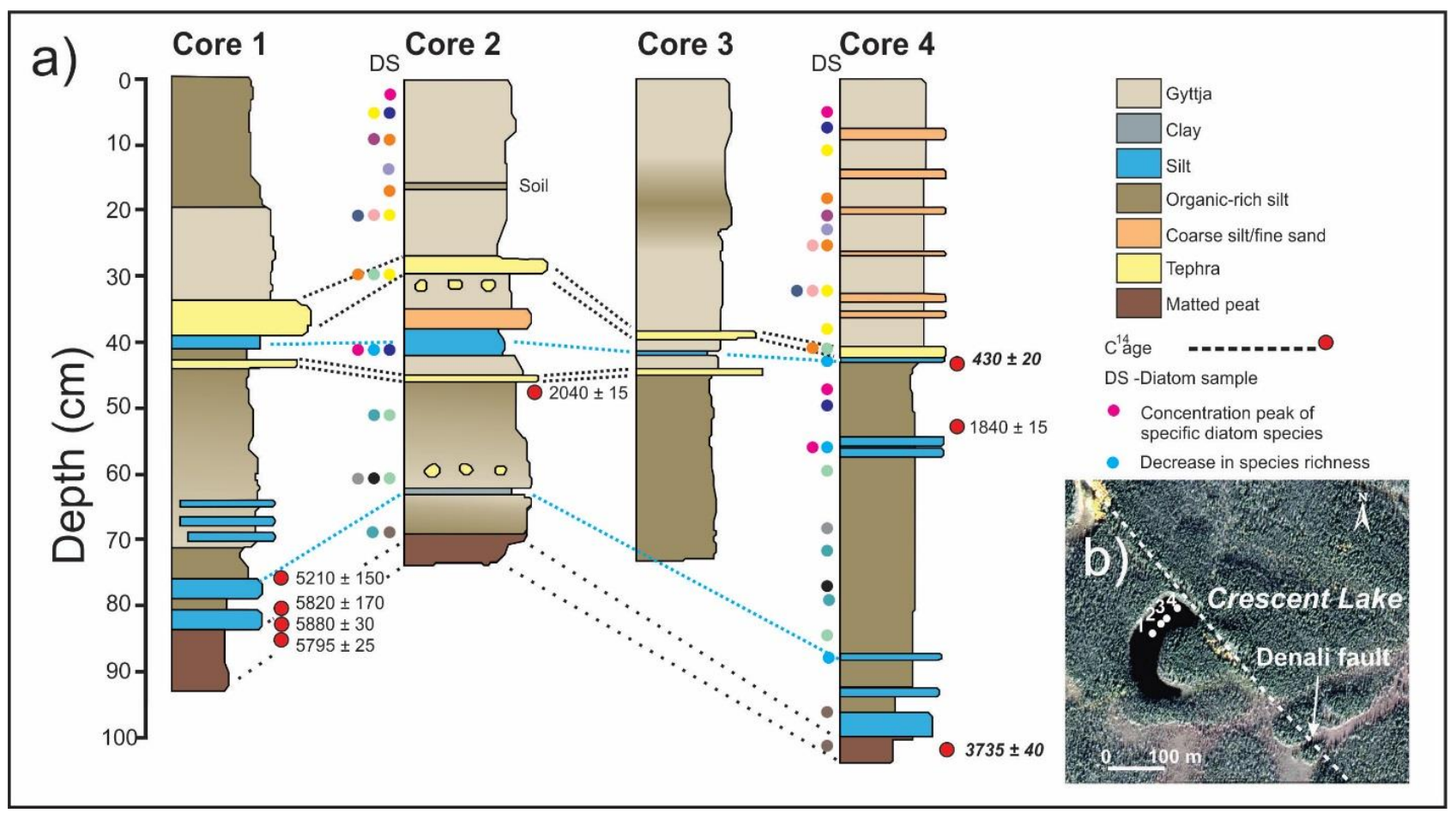

Figure 8. a) Stratigraphy of Crescent Lake sediment cores collected in 2008 and 2010. Stippled black and blue lines indicate inferred correlations of units. Comparable diatom assemblages are color coded (see Appendix 2). b) Locations of the four sediment cores; white dashed line is the Denali fault trace. Based on lithostratigraphic and biostratigraphic correlations, the upper and lower radiocarbon ages in core 4 (italicized) are thought to be too young. Refer to Appendix 2 for color coded peaks in concentrations of specific diatom species; the color reflects the dominant species.

\subsection{Paleoseismic evidence from the Duke River bluff}

Late Pleistocene sediments are exposed continuously over a distance of about $800 \mathrm{~m}$ along the north side of Duke River upstream from the Alaska Highway bridge (site F, Figure 2c; Figures 5 and 9). Two Pleistocene outwash gravel units and an overlying blanket of aeolian sand are exposed in cliffs up to $20 \mathrm{~m}$ high. The upper gravel unit dates to the McConnell Glaciation. It unconformably overlies a lower gravel unit, which predates the McConnell Glaciation (Rampton, 1981; Duk-Rodkin 1999). The two gravel units are locally separated by a thin unit of laminated to 
bedded silt (Figure 9a).

Three types of paleoseismic evidence are apparent in the river bluff. First, strata in the two outwash gravel units are disturbed at the trace of the Denali fault (Figure 9a). The gravel has been uplifted and the bedding disturbed near the top of the bluff. The ground surface where the fault reaches the top of the bluff shows a positive flower structure/mound produced by upward displacement of sediment due to compression from dextral slip movement during one or more earthquakes (Figures 9a, b). Second, several pebbles and cobbles in the two gravel units within the fault zone are fractured and displaced along the fault trace (Figure 10). Third, the aeolian blanket at the top of the bluff contains the older and younger White River tephras, both of which are faulted and folded (Figure 11). It is likely that many paleo-earthquakes have produced the deformation in the Duke River bluff. At least one of them happened after 1200 years ago, because the younger White River tephra is deformed. 


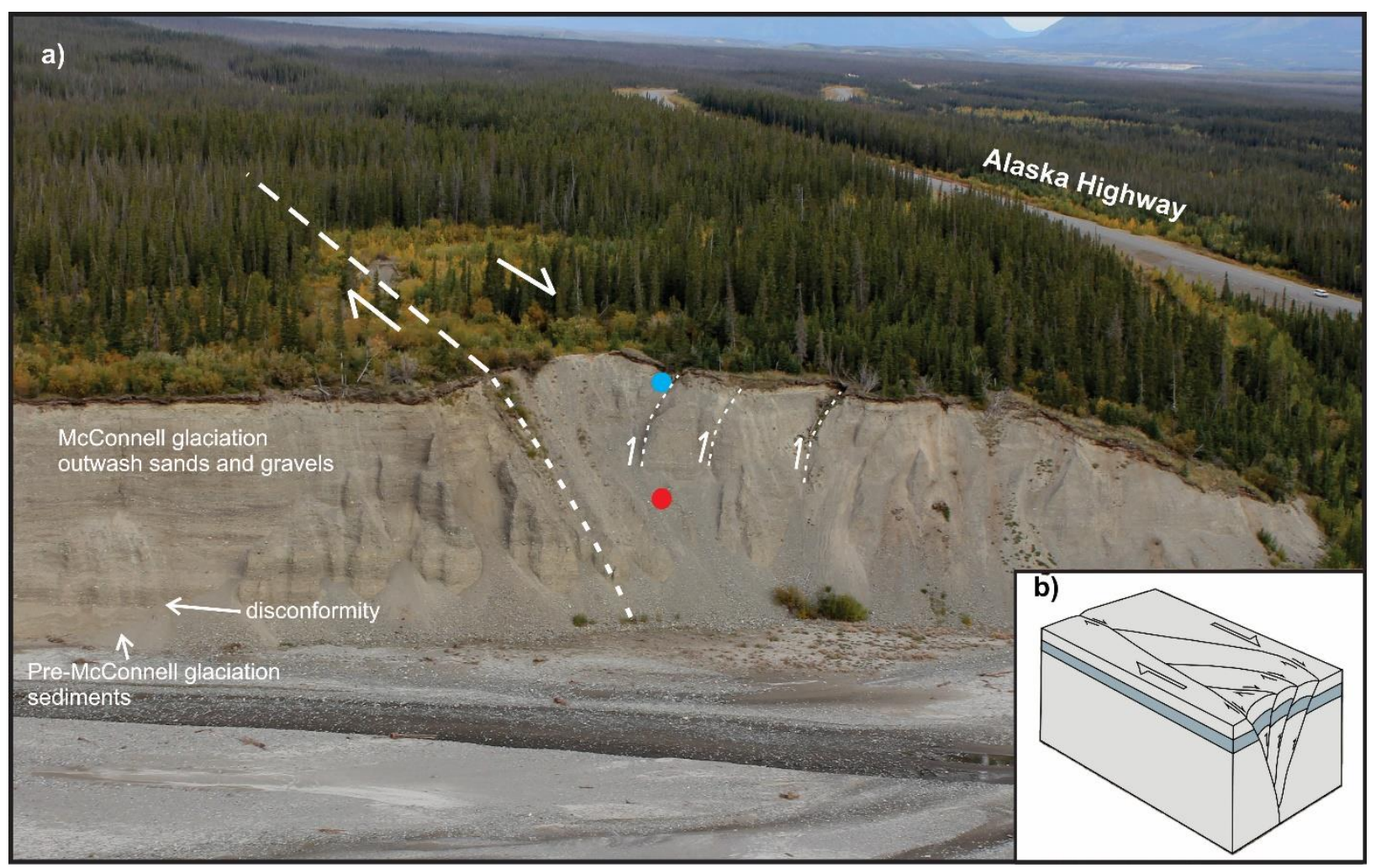

Figure 9. a) Bluff exposing Late Pleistocene outwash gravel on the north side of Duke River west of the Alaska Highway (site F, Figure 2c; Figure 5a). The thicker white dashed line is the approximate trace of the Denali fault plane. Note the difference in the color and structure of the gravel on opposite sides of the fault. The large half arrows indicate fault movement directions. The small half arrows next to the thinner white dotted lines indicate the upward movement of the petals. The red dot indicates the location of the photos in Figure 10, and the blue dot is the location of the photo in Figure 11. b) Block diagram showing a positive flower structure with petals along a dextral strike-slip fault (from Woodcock and Fisher, 1986).

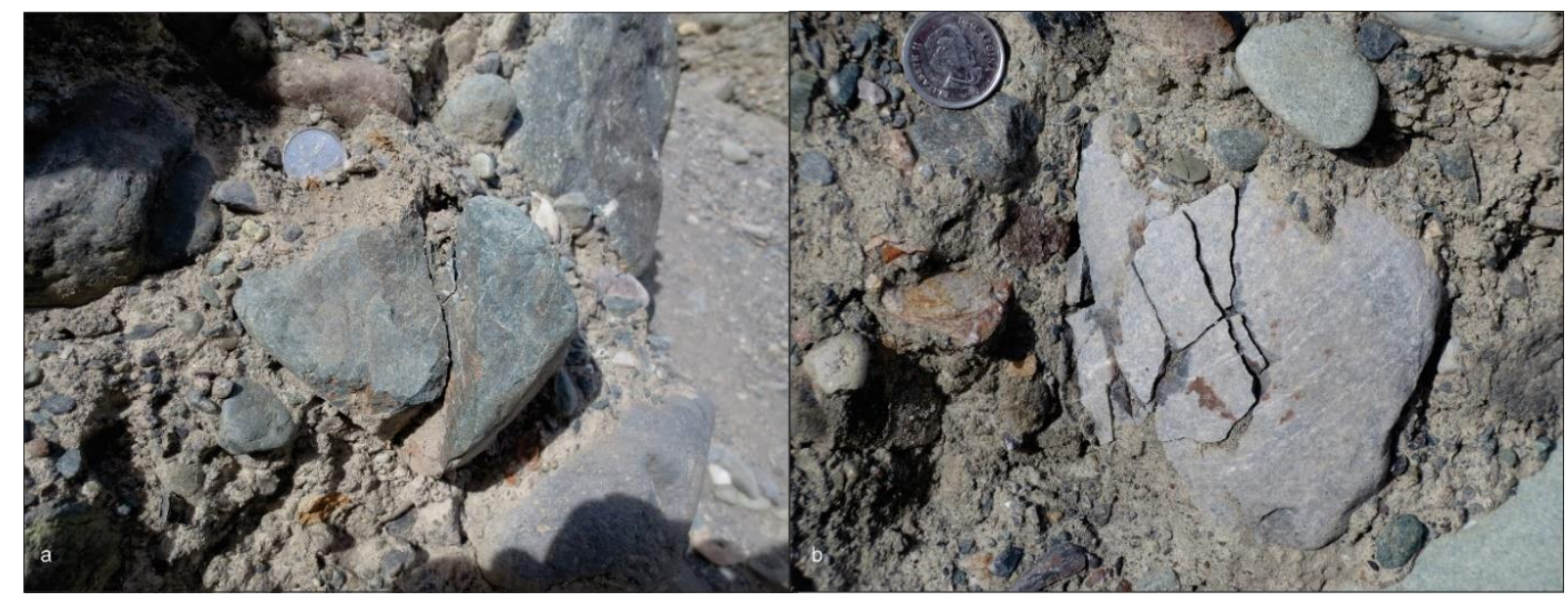

Figures 10. Fractured pebbles and cobbles within the Denali fault zone in the Duke River bluff 
(see Figure 9a for location).

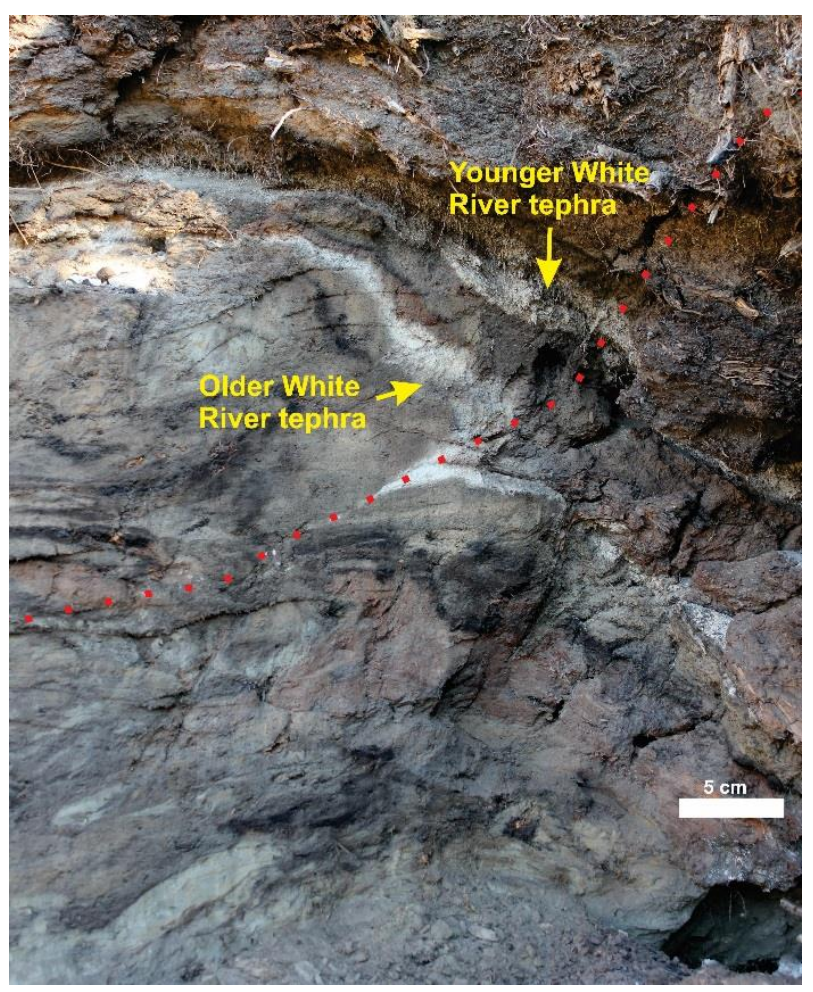

Figure 11. Deformation of aeolian sediments at the top of the Duke River bluff (see Figure 9a for location). Sediments on the left side of the fault (red stippled line) were elevated during one or more earthquakes. Sediments to the right moved downwards, towards the viewer. The last earthquake responsible for this deformation happened after deposition of the younger White River tephra 1200 years ago.

\subsection{Geomorphology and seismicity}

Other researchers have documented surface displacements and the generation of positive flower structures during modern earthquakes in strike-slip tectonic settings. Mavroulis et al. (2017), for example, reported such features along the Cephalonia transform fault in western Greece, near Ateras village, after two strong (magnitude 5.9 and 6.0) crustal earthquakes in 2014. Ulusay et al. (2002) documented fault displacements with flower structures along the North Anatolian fault in Turkey after the 1999 Kocaeli and Düzce earthquakes (magnitude 7.4 
and 7.2, respectively). We are not aware of any earthquakes smaller than the 2014 Cephalonia events that have produced surface or near-surface deformation similar to that observed along the Yukon section of the Denali fault. We thus conclude that the displacements and deformation we describe are the product of moderate to large earthquakes.

\subsection{Timing of past seismic events}

The Crescent Lake sediment cores and the U.S. Geological Survey trenches provide evidence for at least five large earthquakes on the Denali fault over the past 6500-6800 years. Seitz et al. (2008) dated the last three earthquakes to ca. 300-1000 (event 1), 2200 (event 2), and 3000 (event 3) years ago and linked two of the three events to documented prehistoric earthquakes in Alaska. Based on our deepening and re-examination of one of Seitz et al.'s (2008) trenches, we suggest that a fourth earthquake happened about 6000 years ago (event 4) (Figures 7b and 8a). We infer that the sudden formation of Crescent Lake and subsequent deposition of silt 65006800 years ago records yet another large earthquake (event 5), and that silt and clay units and diatom changes in Crescent Lake cores (1,2, and 4) provide evidence for an additional earthquake about 5900-6200 years ago (event 4). Silt beds deposited between 5900 and 1900 years ago may correlate with event 3 of Seitz et al. (2008), which they dated to about 3000 years ago, although this correlation is tentative due to poor chronological constraints. We infer that an earthquake happened between 1900 and 1200 years ago (event 2) based on the silt unit present between the two White River tephras in three of the four cores (1, 2, and 3) and underlying the younger tephra in one core (4). This event may be linked to the 2200 -year event proposed by Seitz et al. (2008), in which case their event 2 is less than 1900 years old. Deformation of the younger White River tephra in the trenches and the Duke River section indicates that the most 
recent large earthquake on this portion of the Denali fault is less than 1200 years old (event 1).

Table 2 summarizes our correlations of earthquakes inferred from the Crescent Lake sediment cores, U.S. Geological Survey trenches, and the Duke River bluff. Trench events 1-4 can be linked to events in Crescent Lake, albeit with much uncertainty in the case of event 3 due to a lack of reliable radiocarbon ages. If trench event 2 correlates with the aforementioned dated silt layer in Crescent Lake, it must be younger than 1900 years old. Deformation associated with the most recent event ( $<1200$ years ago) was not seen in the Crescent Lake cores, possibly because of the narrow diameter of the cores. However, in core 4 close to the fault scarp, coarser sandy layers above the younger White River tephra may represent disturbance due to seismic shaking in the past 1200 years.

Sediment deformation in the trenches is cumulative and due to several large earthquakes, but also induced gravitationally from the edge of the fault scarp. At Crescent Lake, paleoseismic activity is displayed in the sudden change from a wetland to a lake and, subsequently, by pulses (or partitioning) of clastic sediment reflected in changes in diatom assemblages in the lake. Hence, closely spaced but different geological settings reveal recurrent paleoseismic activity over the past 6500-6800 years. Considered together, the data suggest an average recurrence of large earthquakes on the Yukon section of the Denali fault of about 1300 years, which is an order of magnitude lower than on the San Andreas fault in California, which has an average recurrence rate of large earthquakes every 150 years (Schulz and Wallace, 2016). 
Table 2. Ages of inferred earthquakes (cal yr BP).

\begin{tabular}{|c|c|c|c|}
\hline $\begin{array}{c}\text { Seismic } \\
\text { event \# }\end{array}$ & USGS trench & $\begin{array}{c}\text { Crescent Lake } \\
\text { sediment cores }\end{array}$ & Duke River bluff \\
\hline 1 & $300-1200$ & Post 1200 & $300-1200$ \\
\hline 2 & $\sim 2200$ & $1200-1900$ & Not observed \\
\hline 3 & $\sim 3000$ & $1700-5900$ & Not observed \\
\hline 4 & $6000-6200$ & $5900-6200$ & Not observed \\
\hline 5 & Not observed & $6500-6800$ & Not observed \\
\hline
\end{tabular}

\section{Conclusion}

Several independent lines of evidence indicate that the Yukon segment of the Denali fault produced many large earthquakes during the Holocene. Geomorphic observations show that the fault has been active since the area was deglaciated about 12,500 years ago. The active fault trace cuts across glacially streamlined landforms at a low angle and is marked by rectilinear mounds, some of which show right-lateral displacements. The fault also offsets a late Holocene terrace bordering the modern braid plain of Duke River near the north end of Kluane Lake and a Holocene alluvial fan south of the lake.

Sediments deposited in Crescent Lake, which is impounded against the west side of a Denali fault scarp, also contain evidence of coseismic disturbance. The lake formed about 6500- 
6800 years ago, from movement along the nearby fault. Silty layers record detrital sediment inputs from the adjacent fault scarp 6500-6800 and 5900-6200 years ago, possibly several times between about 5900 and 1900 years ago, and again between 1900 and 1200 years ago.

Earthquakes inferred from sediment disturbance in nearby paleoseismic trenches date to ca. $6000,3000,1900-1200$, and 1200-300 years ago. The sediments are interpreted as a negative flower structure resulting from extension by dextral strike-slip movement against the fault scarp.

Paleoseismic disturbance of sediments is also present in a bluff on the north side of Duke River. Late Pleistocene outwash gravel is displaced horizontally and vertically in the form of a positive flower structure. Many cobbles and pebbles within the gravel along the trace of the fault are tectonically broken. A fault mound at the top of the exposure is capped by aeolian sediments including the two White River tephras, both of which are faulted and folded.

The formation of positive flower structures in a strike-slip fault setting requires earthquakes with minimum magnitudes of $\sim 6.0$. Hence, the earthquakes that we have documented are assumed to be at least this size. The average recurrence of large earthquakes on the Yukon portion of the Denali fault is estimated to be $~ 1300$ years. In comparison, recurrence estimates for the Alaska portion of the fault are $~ 1000$ years.

A more detailed study of fault mounds in Shakwak Trench using lidar or high-resolution drone imagery would improve understanding of average slip rates. There likely is better measurable evidence of horizontal and vertical displacements in flatter areas of the fault where slope processes have not modified the mounds. In addition, along streams, there may be mounds that are incised, exposing positive flower structures in the Late Pleistocene sediments. Finally, better age control on Crescent Lake cores would help refine the earthquake history that we infer 
using this paleoseismic proxy.

\section{Acknowledgments}

Our research was funded by Natural Resources Canada's Public Safety Geoscience Program, its Program for Energy Research and Development (1D00.006), and the Natural Sciences and Engineering Research Council of Canada (NSERC) through Discovery Grants to Clague and Menounos as well as a Canada Foundation for Innovation Grant to Menounos. Tyler Dimenna, Tracy Barry, and Richard Franklin drafted, respectively, Figures 2, 7, and 8. The Yukon Geological Survey provided tools and instrumentation. We thank Johannes Koch for assistance in the field. Comments and suggestions by critical reviewers Greg Brooks, Wouter Bleeker, Kristen Kennedy, Eldon Gath, Roy J. Shlemon, Richard Lease, Marti Miller, and an anonymous reviewer have greatly improved the manuscript. This is Geological Survey of Canada Contribution Number 20190100. We also thank the authors of Seitz et al. (2008), who first dug and logged the trenches. Any use of trade, firm, or product names is for descriptive purposes only and does not imply endorsement by the U.S. Government.

\section{References}

Battarbee R.W.; Carvalho, L.; Jones, V.J., Flower, R.J.; Cameron, N.G.; Bennion, H.; and Juggins, S., 2001, Diatoms. In Smol, J.P., Birks, H.J.B., and Last, W.M. (Editors), Vol. 3: Tracking Environmental Change Using Lake Sediments: Kluwer Academic, Dordrecht, Netherlands, pp. 155-202.

Bender, A.M.; and Haeussler, P.J., 2017, Eastern Denali fault surface trace map, eastern Alaska and Yukon, Canada: U.S. Geological Survey Open-File Report 2017-1049, 10 pp.

Brahney, J.; Clague, J.J.; Edward, T.W.D.; and Menounos, B., 2010, Late Holocene paleohydrology of Kluane Lake, Yukon Territory, Canada: Journal Paleolimnology, Vol. 44, No. 3, pp. 873-885.

Bronk Ramsey, C., 2017, Methods for summarizing radiocarbon datasets: Radiocarbon, Vol. 59, 
No. 6, pp. 1809-1833.

Clague, J.J., 1979, The Denali Fault system in southwest Yukon Territory - A geologic hazard? In Current Research Part A: Geological Survey of Canada Paper 79-1A, pp. 169-178.

Clague, J.J., 1982, The role of geomorphology in the identification and evaluation of natural hazards. In Craig, R.G. and Craft, J.L. (Editors), Applied Geomorphology: George Allen and Unwin, London, UK, pp. 17-43.

Clague, J.J.; Evans, S.G.; Rampton, V.N.; and Woodsworth, G.J., 1995, Improved age estimates for the White River and Bridge River tephras, western Canada: Canadian Journal Earth Sciences, Vol. 32, No. 8, pp. 1172-1179.

Clague, J.J.; Luckman, B.H.; Van Dorp, R.D.; Gilbert, R.; Froese, D.; Jensen, B.J.L.; and Reyes, A.V., 2006, Rapid changes in the level of Kluane Lake in Yukon Territory over the last millennium: Quaternary Research, Vol. 66, No. 2, pp. 342-355.

Dodds, C.J., 1995, Denali fault system. In Gabrielse, H., and Yorath, C.J. (Editors), Geology of the Cordilleran Orogen in Canada: Geological Survey of Canada, Ottawa, ON, pp. 656-657.

Dodds, C.J. and Campbell, R.B., 1992, Geology, Southwest Kluane Map Areas 115G and F E1/2, Yukon Territory: Geological Survey of Canada Open File 2188, map 1:250, 000 scale, p.85.

Doig, R., 1991, Effects of strong seismic shaking in lake sediments, and earthquake recurrence interval, Témiscaming, Québec: Canadian Journal Earth Sciences, Vol. 28, No. 9, pp. 13491352.

Duk-Rodkin, A., 1999, Glacial Limits Map of Yukon Territory: Geological Survey of Canada Open File 3694, 1:1,000,000 scale.

Eberhart-Phillips, D.; Haeussler, P.J.; Freymueller, J.T.; Frankel, A.D.; Rubin, C.M.; Craw, P.; Ratchkovski, N.A.; Anderson, G.; Carver, G.A.; Crone, A.J.; Dawson, T.E.; Fletcher, H.; Hansen, R.; Harp, E.L.; Harris, R.A.; Hill, D.P.; Hreinsdóttir, S.; Jibson, R.W.; Jones, L.M.; Kayen, R.; Keefer, D.K.; Larsen, C.F.; Moran, S.C.; Personius, S.F.; Plafker, G.; Sherrod, B.; Sieh, K.; Sitar, N.; and Wallace, W.K., 2003, The Denali fault earthquake, Alaska: A large magnitude, slip-partitioned event: Science, Vol. 300, No. 5622, pp. 1113-1118.

Eisbacher, G.H., 1976, Sedimentology of the Dezadeash flysch and its implications for strikeslip faulting along the Denali fault, Yukon Territory and Alaska: Canadian Journal of Earth Sciences, Vol. 13, pp.1495-1513. doi:10.1139/e76-157.

Elliot, J.L.; Larsen, C.F.; Freymueller, J.T.; and Motyka, R.J., 2010, Tectonic block motion and glacial isostatic adjustment in southeast Alaska and adjacent Canada constrained by GPS measurements: Journal of Geophysical Research, Vol. 115, B09407, 21 p. doi: 10.1029/2009JB007139. 
Fuis, G. and Wald, L.A., compilers, 2003, Rupture in south-central Alaska-The Denali fault earthquake of 2002: U.S. Geological Survey Fact Sheet 014-13, 4 p.

https://pubs.usgs.gov/fs/old.2003/fs014-03/

Grantz, A., 1966, Strike-slip faults in Alaska: Unpublished Ph.D. thesis, Department of Geology, Stanford University, Stanford, CA, 158 p.

Haeussler, P.J., 2008, An overview of the neotectonics of interior Alaska: Far-field deformation from the Yakutat microplate collision, In Freymuller, J.T., Haeussler, P.J., Wesson, R.L., Ekström (Editors), Active Tectonics and Seismic Potential of Alaska: American Geophysical Union, Washington, DC, pp. 83-108.

Haeussler, P.J., 2009, Surface rupture map of the 2002 M7.9 Denali fault earthquake, Alaska: Digital Data: U.S. Geological Survey Data Series Report DS-0422, 9 p.

Haeussler, P.J.; Matmon, A.; Schwartz, D.P.; and Seitz, G.G., 2017, Neotectonics of interior Alaska and the late Quaternary slip rate along the Denali fault system: Geosphere, Vol. 13, No. 5, pp. 1-19.

Haeussler, P.J.; Schwartz, D.P.; Dawson, T.E.; Stenner, H.D.; Lienkaemper, J.J.; Sherrod, B.; Cinti, F.R.; Montone, P.; Craw, P.; Crone, A.J.; and Personius, S.F., 2004, Surface rupture and slip distribution of the Denali and Totschunda faults in the 3 November 2002 M 7.9 earthquake, Alaska: Bulletin of the Seismological Society of America, Vol. 94, No. 6B, pp. S23-S52.

Harding, T.P., 1985, Seismic characteristics and identification of negative flower structures, positive flower structures, and positive structural inversion: American Association Petroleum Geologists Bulletin, Vol. 69, No. 4, pp. 582-600.

Heginbottom, J.A., 1995, Canada Permafrost: National Atlas of Canada: Natural Resources Canada, Map MCR 4177 ( $5^{\text {th }}$ edition), 1:7,500,000 scale.

Heginbottom, J.A. and Radburn, L.K.,1992, Permafrost and Ground Ice Conditions of Northwestern Canada: Geological Survey of Canada Map1691A, 1:1,100,000 scale.

Huscroft, C.A.; Lipovsky, P.S.; and Bond, J.D., 2004, A Regional Characterization of Landslides in the Alaska Highway Corridor, Yukon: Yukon Geological Survey Open File Report 2004-18, 65 p.

Kelly, M.G.; Bennion, H.; Cox, E.J.; Goldsmith, B.; Jamieson, J.; Juggins, S.; Mann, D.G.; and Telford, R.J., 2005, Common Freshwater Diatoms of Britain and Ireland: An Interactive key: CD-ROM, Bristol Environment Agency, UK.

Klassen, R.W., 1987, The Tertiary -Pleistocene Stratigraphy of the Liard Plain, Southeastern Yukon Territory: Geological Survey of Canada Paper 86-17, 16 p.

Krammer, K. and H. Lange-Bertalot, 1985, Naviculaceae Bibliotheca Diatomologia, Band 9: J. Cramer, Berlin-Stuttgart, 230 p. 
Krammer, K.; and Lange-Bertalot, H., 1986, Bacillariophyceae Süsswasser flora von Mitteleuropa, Band 2/1: Gustav Fischer Verlag, Stuttgart, New York, 876 p.

Krammer, K. and Lange-Bertalot, H., 1988. Bacillariophyceae, Süsswasserflora von Mitteleuropa, Band 2/2: VEB Gustav Fischer Verlag, Jena, 596 p.

Krammer, K.; and Lange-Bertalot, H., 1991, Bacillariophyceae Süsswasserflora von Mitteleuropa, Band 2/3: Gustav Fischer Verlag, Stuttgart, Jena, 576 p.

Krammer, K.; and Lange-Bertalot, H., 2000, Bacillariophyceae Süßwasserflora von Mitteleuropa, Band 2/5, Part 5: Gustav Fischer Verlag, Stuttgart, Jena, pp. 2-12.

Lanphere, M.A., 1978, Displacement history of the Denali fault system, Alaska and Canada: Canadian Journal of Earth Sciences, Vol. 15, No. 5, pp. 817-822.

Lerbekmo, J.F., 2008, The White River Ash: Largest Holocene Plinian tephra: Canadian Journal Earth Sciences, Vol. 45, No. 6, pp. 693-700.

Lipovsky, P.S.; Seitz, G.; Haeussler, P.J.; Crone, A.J.; Schwartz, D.P.; Clague, J.J.; Mazotti, S.; and Cobbett, R., 2009, Neotectonic investigations in southwest Yukon: Abstract, Canadian Quaternary Association Meeting, Vancouver, BC.

Lotter, A.; Pienitz, R.; and Schmidt, R., 2010, Diatoms as indicators of environmental change in subarctic and alpine regions, In Smol, J.P. and Stoermer, E.F. (eds), The Diatoms: Applications for the Environmental and Earth Sciences, Second Edition: Cambridge University Press, Cambridge, UK, pp. 231-248.

Lowey, G.W., 1998, A new estimate of the amount of displacement on the Denali fault system based on the occurrence of carbonate megaboulders in the Dezadeash Formation (JuraCretaceous), Yukon, and the Nutzotin Mountains sequence (Jura-Cretaceous), Alaska: Bulletin Canadian Petroleum Geology, Vol. 46, No. 3, pp. 379-386.

Marechal, A.; Ritz, J.-F.; Ferry, M.; Mazzotti, S.; Blard, P.-H.; Braucher, R.; and Saint-Carlier, R., 2018, Active tectonics around the Yukata indentor: New geomorphological constraints on the eastern Denali fault, Totschunda and Duke River faults: Earth Planetary Science Letters, Vol. 482, pp. 71-80.

Mathews, W.H., 1986, Physiographic Map of the Canadian Cordillera: Geological Survey of Canada, Ottawa, ON, map, 1: 5,000,000 scale.

Matmon, A.; Schwartz, D.P.; Haeussler, P.J.; Finkel, R.; Lienkaemper, J.J.; Stenner, H.D.; and Dawson, T.E., 2006, Denali fault slip rates and Holocene-late Pleistocene kinematics of central Alaska: Geology, Vol. 34, No. 8, pp. 645-648.

Mavroulis, S.; Carydis, P.; Alexoudi, V.; Grambas, A.; and Lekkas, E., 2017, The JanuaryFebruary 2014 Cephalonia (Ionian Sea, western Greece) earthquakes: Tectonics and seismological facts. Proceedings $16^{\text {th }}$ World Conference on Earthquakes, Santiago, Chile, Paper 
413, $12 \mathrm{p}$.

McCalpin, J.P.; Rockwell, T.K.; and Weldon II, R.J., 2009, Paleoseismology of strike-slip tectonic environments, In McCalpin, J.A. (Editor), Paleoseismology: International Geophysics Sseries, Vol. 95, $2^{\text {nd }}$ edition, Chapter 6, pp. 421-496, doi: 10.1016/S0074-6142(09)95006-9

McGimsey, R.G.; Richter, D. H.; DuBois, G.D.; and Miller, T.P., 1990, A postulated new source for the White River Ash, Alaska:In Geologic Studies in Alaska: U.S. Geological Survey Bulletin 1999, 7 p.

Morell, K.D.; Regalla, C.; Amos, C.; Bennett, S.; Leonard, L.; Graham, A.; Reedy, T.; Levson, V.; and Telka, A., 2018, Holocene surface rupture history of an active forearc fault redefines seismic hazard in southwestern British Columbia, Canada: Geophysical Research Letters, Vol. 45, pp. 11605-11611. doi/10.1029/2018GL078711.

Northern Climate ExChange, 2013, Burwash Landing and Destruction Bay Landscape Hazards: Geological Mapping for Climate Change Adaptation Planning: Yukon Research Centre, Yukon College, Whitehorse, Yukon, 111 p. and 2 maps.

Patrick, R. and Reimer, C.W., 1966, The Diatoms of the United States Exclusive of Alaska and Hawaii, Vol. 1: Monographs of the Academy of Natural Sciences, Philadelphia, PA, No. 13, 688 p.

Patrick, R. and Reimer, C.W., 1975, The Diatoms of the United States Exclusive of Alaska and Hawaii, Vol. 2: Monographs of the Academy of Natural Sciences, Philadelphia, PA, No. 13, $213 \mathrm{p}$.

Rampton, V.N., 1979, Surficial Materials of Kluane Lake National Park, Yukon Territory: Geological Survey of Canada Map 1979-14, 1:250,000 scale.

Rampton, V.N., 1981, Surficial Materials and Landforms, Kluane National Park, Yukon Territory: Geological Survey of Canada Paper, 37 p.

Reimer, P.J.; Bard, E.; Bayliss, A.; Beck, J.W.; Blackwell, P.G.; Ramsey, C.B.; Buck, C.E.; Cheng, H.; Edwards, R.L.; Friedrich, M.; Grootes, P.M.; Guilderson, T.P.; Haidason, H.; Hajdas, I.; Hatté, C.; Heaton, T.J.; Hoffmann, D.L.; Hogg, A.G.; Hughen, K.A.; Kaiser, K.F.; Kromer, B.; Manning, S.W.; Niu, M.; Reimer, R.W.; Richards, D.A.; Scott, E.M.; Southon, J.R.; Staff, R.A.; Turney, C.S.M.; and van der Plicht, J., 2013, IntCal13 and Marine13 radiocarbon age calibration curves 0-50,000 years cal BP: Radiocarbon, Vol. 55, No. 4, pp. 1869-1887.

Schulz, S.S. and Wallace, R.E., 2016, The San Andreas Fault: U.S. Geological Survey, https://pubs.usgs.gov/gip/earth3/

Seitz, G.C.; Haeussler, P.J.; Crone, A.J.; Lipovsky, P.; and Schwartz, D.P., 2008, Eastern Denali fault slip rate and paleoseismic history, Kluane Lake area, Yukon Territory, Canada. American Geophysical Union, San Francisco, CA, Poster T53B-1947. http://www.geology.gov.yk.ca/pdf/AGU_Denali_Fault_2009v1.pdf 
Spaulding, S.A.; Pool, J.; Castro, S.; and Hinz, F., 2010, Species within the genus Encyonema Kützing, including two new species Encyonema reimeri sp. nov. and E. nicafei sp. nov. and E. stoermeri nom. nov., stat. nov.: Proceedings Academy Natural Sciences Philadelphia, Vol. 160, No. 1, pp. 57-71.

Ulusay, R.; Aydan, Ö.; and Hamada, M., 2002, The behaviour of structures built on active fault zones: Examples from the recent earthquakes in Turkey: Structural Engineering/Earthquake Engineering, Vol. 19, No. 2, pp. 149-167.

Veselá, J., 2015, Eunotia panda: Diatoms of North America. Retrieved December 15, 2018. https://diatoms.org/species/eunotia_panda

Woodcock, N.H. and Fischer, M., 1986, Strike-slip duplexes: Journal Structural Geology, Vol. 8, No. 7, pp. 725-735. 
Appendix 1: Photomosaics of U.S. Geological Survey trenches T2 and T3.

\section{USGS Trench 2 looking north}

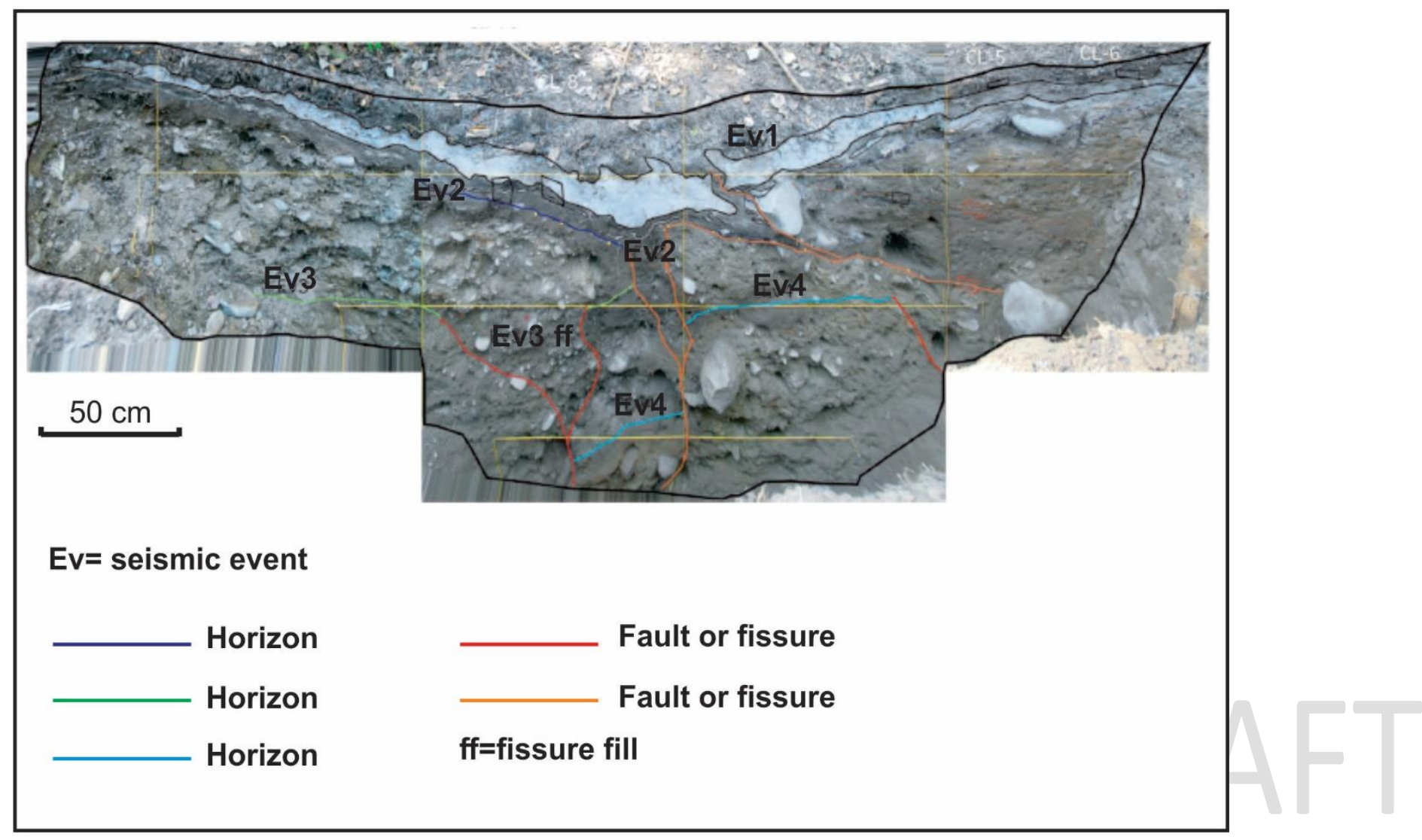

Figure 1. Photomosaic of trench T2 looking north. 


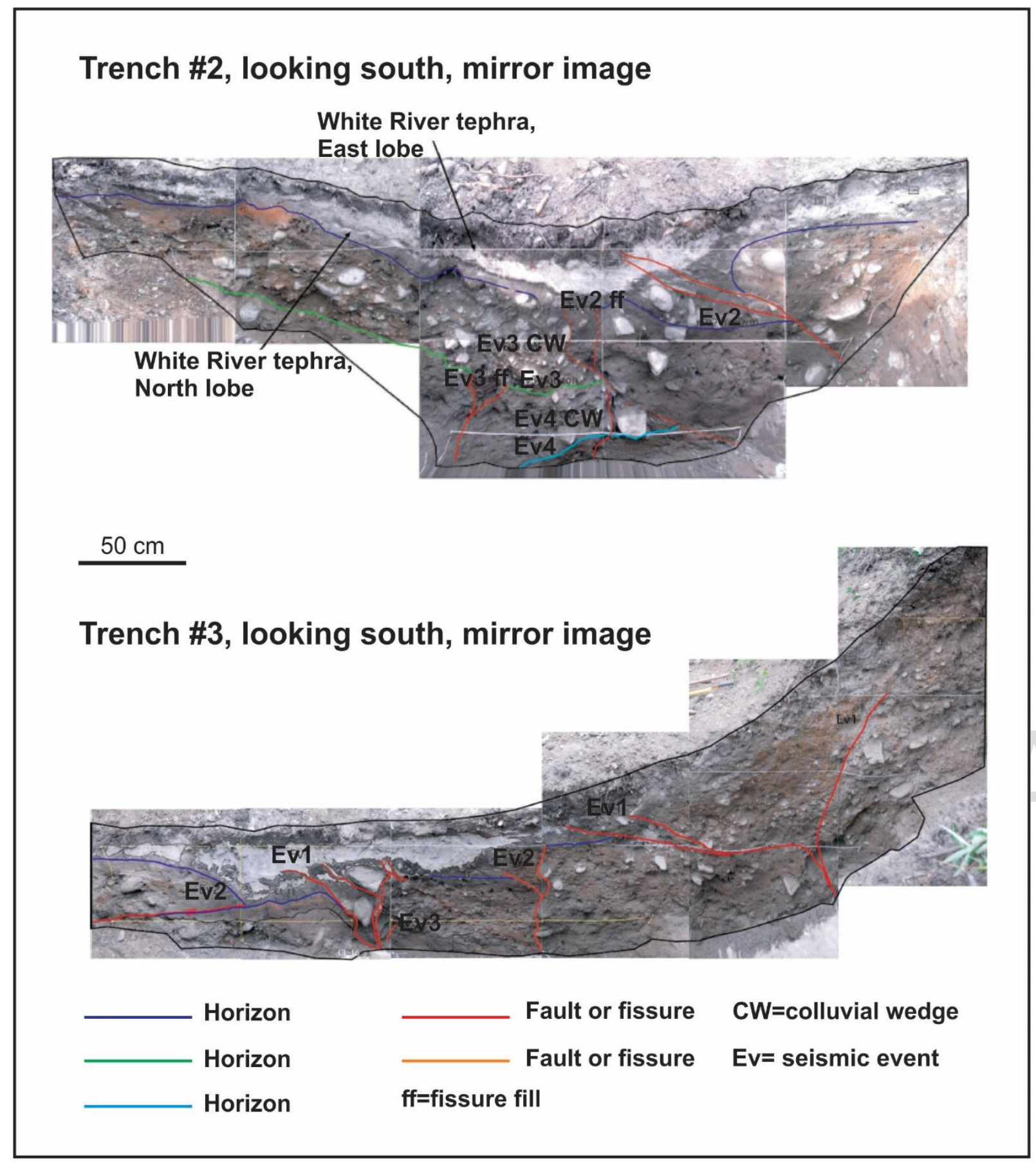

Figures 2 and 3. Photomosaic of the trenches T2 and T3, looking south.

\section{Reference:}

Seitz, G.C.; Haeussler, P.J.; Crone, A.J.; Lipovsky, P.; and Schwartz, D.P., 2008, Eastern Denali fault slip rate and paleoseismic history, Kluane Lake area, Yukon Territory, Canada. American Geophysical Union, San Francisco, CA, Poster T53B-1947. http://www.geology.gov.yk.ca/pdf/AGU_Denali_Fault_2009v1.pdf 
Appendix 2: Supplementary figures, table, and interpretation of stratigraphic changes in diatom assemblages.
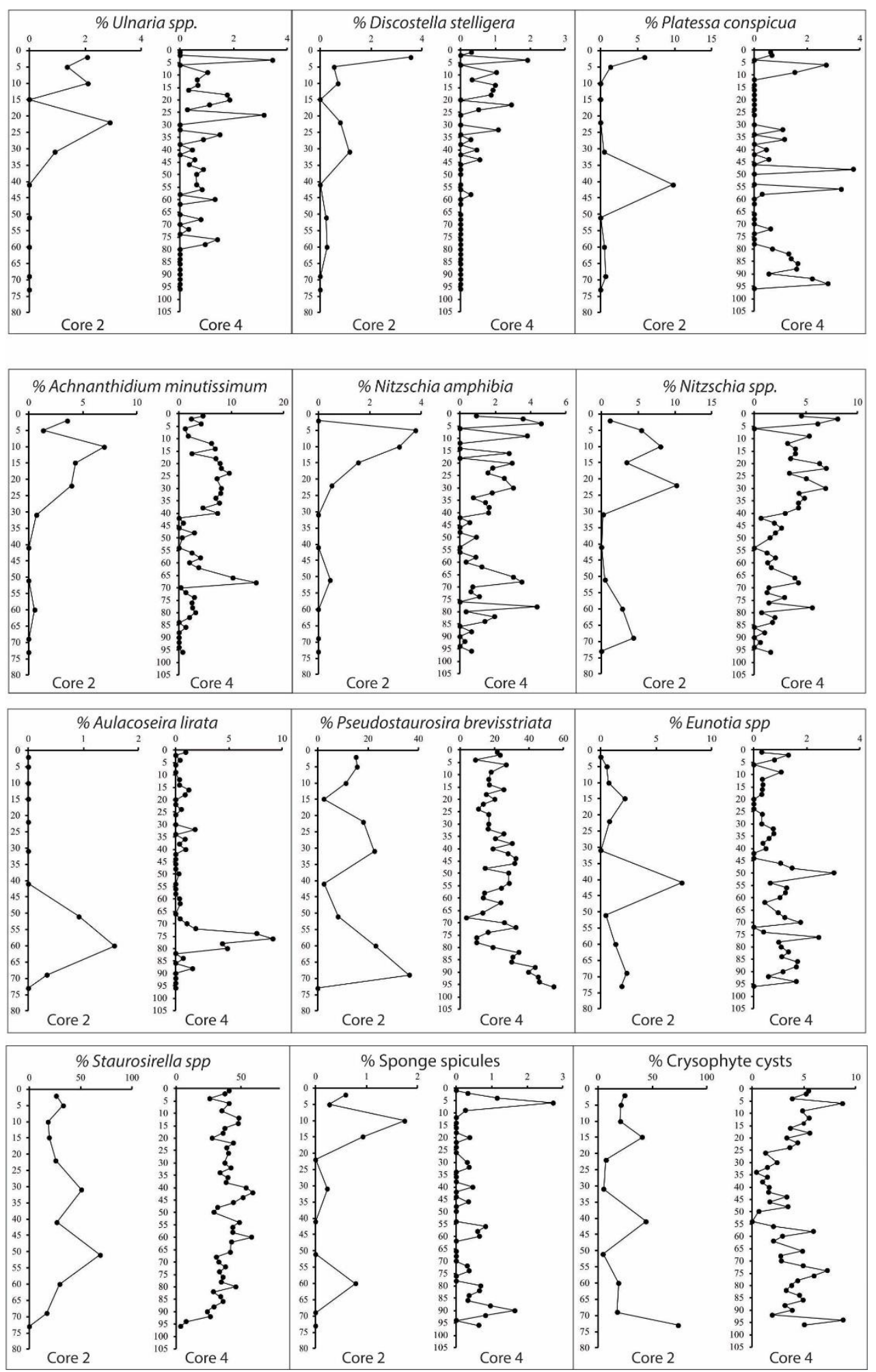
Supplementary Figure 1. Comparison of diatom community composition in cores 2 and 4, showing distinct communities associated with different time intervals.

Diatoms $\mu \mathrm{g}$
sediment ${ }^{-1}$

Supplementary Figure 2. Diatom stratigraphy of core 2 as percent of community composition.

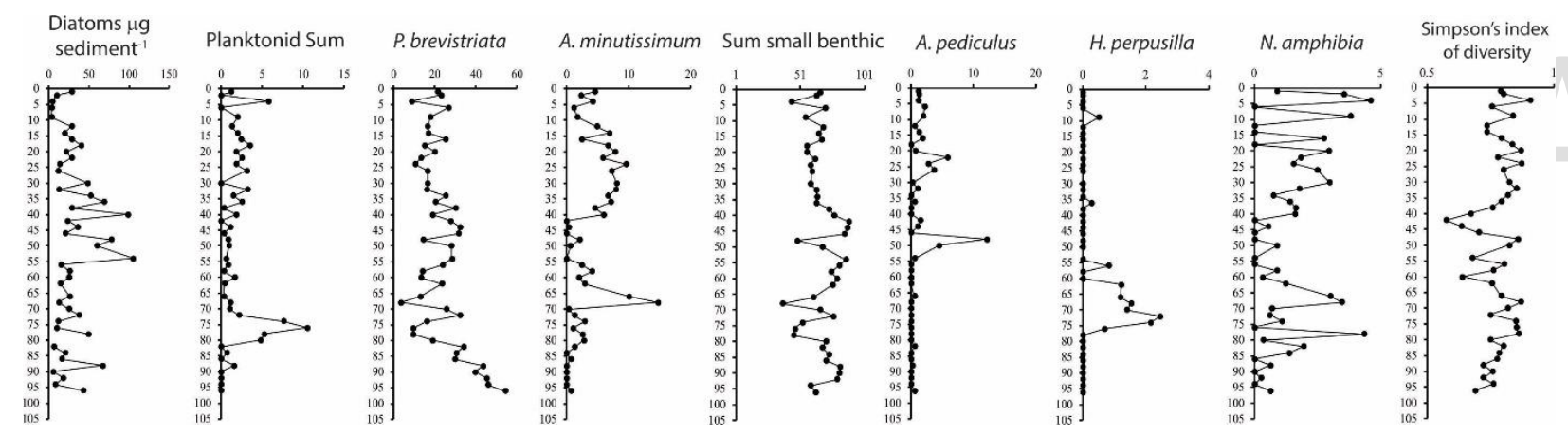

Supplementary Figure 3. Diatom stratigraphy of core 4 as percent of community composition. 
Appendix Table 1. Peak concentrations of diatom species in samples from cores 2 and 4;

\begin{tabular}{|c|c|c|c|}
\hline $\begin{array}{c}\text { Core } 2 \\
\mathrm{~cm} \text { depth }\end{array}$ & \multirow[b]{2}{*}{ peak $P$. conspict } & \multirow{2}{*}{ Peak concentration } & \multirow{2}{*}{$\begin{array}{l}\text { Core } 4 \\
\mathrm{~cm} \text { depth } \\
6\end{array}$} \\
\hline 2 & & & \\
\hline 2 & low N. amphibia & & 2 \\
\hline 5 & peak $P$. brevistriata & - & 12 \\
\hline 5 & peak Eunotia panda & - & 9 \\
\hline 10 & peak Achnanthidium minutissimum & - & 22 \\
\hline 10 & Luticola sp & - & 18 \\
\hline 10,15 & Hantzschia amphioxis & - & 24 \\
\hline 18 & possibly correlate due to low concer & ntraiton of diatoms & 28 \\
\hline 18 & Luticola sp & + & 26 \\
\hline 22 & peak planktonic Ulnaria sp. & - & 26 \\
\hline 22 & peak $P$. brevistriata & - & 34 \\
\hline 22 & peak Sellaphora sp & - & 34 \\
\hline $22-31$ & peak $P$. brevistriata & - & $32-46$ \\
\hline $22-31$ & low cyst numbers & & 26 \\
\hline 31 & peak Staurosirella. pinnata and sma & all benthic species & 42 \\
\hline 31 & Nitz. amphibia increases & & 42 \\
\hline 41 & peak $P$. conspicua & - & 48 or 56 \\
\hline 41 & peak total monoraphics & & 50 \\
\hline 41 & peak Eunotia panda & - & 50 \\
\hline 51 & peak Staurosirella. pinnata and sma & all benthic species & 60 \\
\hline 51 & low cyst numbers & & $52-54$ or \\
\hline 51 & low N. amphibia & & 68 \\
\hline $51-69$ & peak Aulacoseira & - & $72-80$ \\
\hline$\sim 60$ & peak Tabellaria flocculosa & $\bullet$ & 78 \\
\hline 60 & Staurosirella. pinnata begin to incre & ease & $86-92$ \\
\hline 60 & Eunotia praerupta increases & $\bullet$ & $68 ?$ \\
\hline 69 & peak Nitzschia & $\bullet$ & 80 \\
\hline
\end{tabular}


Notes: Color-coded diatom species are plotted in Figure 8a to facilitate understanding of the stratigraphy. The biostratigraphic correlations indicate that the upper and lower ages in core 4 (bold italics) are anomalously young.

\section{Core 4 biostratigraphic interpretations}

\section{5-98 cm: Lake inception}

\section{Lake inception, likely due to earthquake}

There are very few diatom frustules present below $98 \mathrm{~cm}$ and it is likely that this interval represents a change from a terrestrial environment to a lake.

\section{$96-0 \mathrm{~cm}$}

Diatoms cycle though dominant species, indicating a shift from a shallow saline system to a deeper freshwater lake. There are also shifts in dominant species type, which indicates a change in benthic habitat with changes in depth.

\section{6-92.5 cm: Dark brown peaty silt}

\section{Lake is shallow, possibly brackish}

Several observations support this interpretation. 1) There is a peak in sponge spicules at $90 \mathrm{~cm}$ $(60 \mathrm{~cm}$ in core 2). The presence of sponge spicules indicates that the core site was shallower during this period. 2) There are higher concentrations of large benthic species, in particular Stauroneis, a genus that often prefers brackish water, as well as the larger Sellaphora pupula and Pinnularia species. 3) The small benthic species Pseudostaurosira brevistriata, which is present in higher concentrations during this period, prefers shallow conditions in diatom calibration sets from the Yukon (Pienitz et al., 1995). This and other small benthic species are present during this interval and may represent pioneering benthic communities (Lotter et al., 2010). 4) There is an absence of planktonic species throughout this period. 5) During slidemaking, the sediment was coarse, so much so that it interfered with the binding of the coverslip to the slide. These sediments required sieving prior to mounting on a slide. 6) A white salt-like precipitate formed on the coverslips, indicating a higher soluble salt content. 7) Core 2 contains high concentrations of Eunotia praerupta, which is commonly associated with near shoreline habitats, vegetation, or peat (Sawai et al., 2002).

\section{5-55 cm: Gyttja with laminae of olive gray mud; sharp lower contact}

\section{Lake deepens and benthic habitat experiences some changes}




\section{Deepest period was probably $80-70 \mathrm{~cm}$}

From approximately $88 \mathrm{~cm}$ to $78 \mathrm{~cm}$, there are large increases in concentrations of the epiphytic and/or planktonic Tabellaria flocculosa and then the planktonic Aulacoseira lirata $(80-70 \mathrm{~cm})$. This shift in species composition likely indicates an increase in lake depth, such that mixing conditions can occur. Other Aulocaoseira species have been linked to strong mixing, as they are a heavily silicified diatom and require active mixing to stay afloat (Sherman et al., 1998). Thus, the presence of this species likely represents a deepening of the lake such that longer spring circulation occurs (Horn et al., 2011). Anderson et al. (2007) determined that this time period was wetter in southern Yukon based on a lake level reconstruction from a nearby lake. Core 2 also shows an increase in Aulacoseira lirata at this time, although more generally an up-core increase in planktonic taxa. Because both cores show this upward increase in planktonic taxa, the lake may have further deepened.

Following this period, from 78-60 cm ( $~ 51$ in core 2$)$, there is an increase in Humidophyla gallixa, and small benthic monoraphids (Sellaphora atomoides. Rossithidium pussillum, and Achnanthidium minutissiumum). In core 2, there is also an increase in small benthic species. In general, many Achnanthidium and benthic species (including Stauroseira, Stauorsirella, and Pseudostaurosira) are not motile and are attached either to sediment grains or to vegetation. Thus their increase in abundance through this period may indicate changes in substrate and nutrient availability. The shift from benthic to planktonic and then back to benthic suggests that the lake deepened and then perhaps shallowed.

\section{4 and $40 \mathrm{~cm}$ : Changes in diatom abundance and composition}

\section{Possible earthquake intervals}

At both 54 and $40 \mathrm{~cm}$ in core 4, there are distinct changes in diatom abundance and composition, suggesting a shift in habitat and productivity following abrupt disturbances. Similarly, there is a silty layer with few diatoms at $41 \mathrm{~cm}$ in core 2, suggesting a disturbance that brought terrigenous sediment into the lake.

Core 4

- Spike in diatom concentrations

- Drops in cryosophyte cysts

- Loss of species richness (Simpson's Index)

- Declines in some benthic species, specifically Nitzschia spp. and Achnanthidium spp. Increases in benthic taxa that are more tolerant and are often 'pioneers' in new habitats (Lotter et al., 2010)

Core 2

- $41 \mathrm{~cm}$ has few diatoms, indicating the introduction of terrigenous material into the lake.

- The main diatom found in this sample is Eunotia panda, which typically lives in shallow nearshore environments or bogs (Veselá, 2015) 
It is possible that these intervals record earthquake disturbance. An earthquake might be expected to redistribute nearshore nutrient-rich sediments might introduce silt and clay in the water body. Larger benthic species that are sensitive to turbidity (e.g. Nitzschia amphibia) are replaced by small benthic species that are more tolerant of poor light conditions and quickly reproduce to colonize new benthic habitats. The decrease in cryosphyte stomatocysts may be a result of a temporary increase in nutrient concentrations due to the introduction of terrigenous sediment (Sandgren, 1991; Smol and Stoermer, 2010).

\section{0-0 cm: Dark brown organic rich sand silty mud $(30-0 \mathrm{~cm}$ in core 2$)$}

\section{Establishment of current conditions}

From $40 \mathrm{~cm}$ to the sediment surface, there is a transition to the modern lake. The slight increase in planktonic communities may suggest a minor deepening of the lake through this period. Throughout this part of core 4, there is a balance of planktonic (Discostella stelligera, Ulnaria ulna) and benthic species (Eunotids, Achnanthidium). Crysophyte cysts and Cocconeis placentula also increase through this period. Taken together, these changes suggest a deepening of the lake and lower nutrient conditions. Cocconeis placentula can rapidly colonize new areas (Kelly et al., 2005), which supports a deepening lake. In addition, a decrease in epiphytic species and an increase in Nitzschoid species, which are motile among sediment (Kelly et al., 2005), may indicate a reduction in the relative amount of benthic vegetation cover with deepening of the lake. Kingsbury et al. (2012) documented species distributions across depth gradients in a variety of boreal lakes. They found that Discostella stelligera is found predominantly in the deepest zone of the lakes they studied, which range from 7 to $25 \mathrm{~m}$ in depth. Naviculoids and small Fragillaria species (now reclassified as Stauroseira, Staurosirella, and Pseudostaurosira) were found at mid-depths $(2-15 \mathrm{~m})$ and in shallower water $(0-7 \mathrm{~m})$.

\section{Summary of the interpreted changes in lake depth and water chemistry in core 4:}

1. $\quad 96-88$ cm: Shallow water, higher salinity/nutrients. Sponges, Pseudostaurosira brevistriata (mesotrophic), and Stauroneis and Sellaphora, which are large unattached motile diatoms. Pioneer species indicate inception of the lake.

2. 86 cm: Deepening, planktonic species emerge; Tabellaria flocculosa (either planktonic or benthic) and Aulacoseira lirata, which requires active mixing to remain afloat.

3. $\quad 80-70 \mathrm{~cm}:$ Dominance of Aulacoseira lirata in planktonic community. Lake perhaps deepest, and/or longer spring turnover.

4. 70-60 cm: Lake possibly shallower. Emergence of epiphytic species (Achnanthidium minutissiumum, Humidophila gallica (often aerophyllic), and Nitzschia spp).

5. $\quad \sim 54$ and $\mathbf{4 0} \mathbf{c m}$ : Loss of species richness, particularly epiphytes (e.g. Nitzschia spp. Achnanthidium minutissiumum); proliferation of the episammic pioneer species Staurosirella pinnata, as well as Pseudostaurosira brevistriata. These intervals appear 
to represent disturbances, suggesting that earthquakes caused increased sediment delivery to the lake.

6. 40-0 cm: Establishment of current conditions; lake possibly deepens with a reduction in nutrients. Reemergence of epiphytic species (Achnanthidium minutissiumum, naviculoids, Nizschia, and Cocconeis spp,), as well as planktonic species and Discostella stelligera. Diversity increases again, and productivity decreases.

\section{References}

Anderson, L.; Abbott, M.B.; Finney, B.P.; and Burns, S.J., 2007, Late Holocene moisture balance variability in the southwest Yukon Territory, Canada: Quaternary Science Reviews, Vol. 26, No.1, pp. 130-141.

Horn, H.; Paul, L.; Horn, W.; and Petzoldt, T., 2011, Long-term trends in the diatom composition of the spring bloom of a German reservoir: Is Aulacoseira subarctica favoured by warm winters?: Freshwater Biology, Vol. 56, No. 12, pp. 2483-2499.

Kelly, M.G.; Bennion, H.; Cox, E.J.; Goldsmith, B.; Jamieson, J.; Juggins, S.; Mann, D.G.; and Telford, R.J., 2005, Common Freshwater Diatoms of Britain and Ireland: An Interactive Key. Bristol Environment Agency, Bristol, UK, interactive CD-ROM.

Kingsbury, M.V.; Laird, K.R.; and Cumming, B.F., 2012, Consistent patterns in diatom assemblages and diversity measures across water-depth gradients from eight boreal lakes from north-western Ontario (Canada): Freshwater Biology, Vol. 57, No.6, pp. 1151-1165.

Lotter, A.; Pienitz, R.; and Schmidt, R., 2010, Diatoms as indicators of environmental change in subarctic and alpine regions, In Smol, J.P. and Stoermer, E.F. (Editors.), The Diatoms: Applications for the Environmental and Earth Sciences, Second Edition: Cambridge University Press, Cambridge, UK, pp. 231-248.

Pienitz, R.; Smol, J.; and Birks H.J., 1995, Assessment of freshwater diatoms as quantitative indicators of past climatic change in the Yukon and Northwest Territories, Canada: Journal of Paleolimnology, Vol. 13, No.1, pp. 21-49.

Sandgren, C., 1991, Chrysophyte reproduction and resting cysts: A paleolimnologist's primer: Journal Paleolimnology, Vol. 5, No. 1, pp. 1-9.

Sawai, Y.; Nasu, H.; and Yasuda, Y., 2002, Fluctuations in relative sea-level during the past $3000 \mathrm{yr}$ in the Onnetoh estuary, Hokkaido, northern Japan: Journal of Quaternary Science, Vol. 17, No. 5-6, pp. 607-622.

Sherman, B.S.; Webster, I.T.; Jones, G.J.; and Oliver, R.L, 1998, Transitions between Auhcoseira and Anabaena dominance in a turbid river weir pool: Limnology and Oceanography, Vol. 43, No. 8, pp. 1902-1915. 
Smol, J.P.; and Stoermer, E. F., 2010, The Diatoms: Applications for the Environmental and Earth Sciences. Cambridge University Press, Cambridge, UK, 667 p.

Veselá, J., 2015, Eunotia panda: Diatoms of North America. Retrieved December 15, 2018. Retrieved from https://diatoms.org/species/eunotia_panda. 